\title{
İstanbul Üniversitesi Rektörlüğü Merkez Binası Avize ve Apliklerinin Restorasyon Öncesi Belgeleme Çalışmaları ve Onarım Önerileri
}

\author{
Proposal for the Pre-Restoration Documentation Work and Repair of the Chandeliers \\ and Wall Lights of Istanbul University Rectorate Central Building
}

\author{
Işıl Özsait-Kocabaş̧ $\odot$, Gülder Emre* ${ }^{*}$
}

\section{Öz}

İstanbul Üniversitesi Rektörlük Merkez Binası'nda gerçekleştirilen restorasyon sırasında, yerinden sökülmüş olan avize ve aplikler, rektörlük bahçesindeki konteynırlarda koruma altına alınmıştır. Bu aydınlatma armatürlerinin onarımlarının yapılabilmesi için gerekli olan işlemlerin belirlenmesine yönelik çalışmalar, i.ü. Edebiyat Fakültesi Taşınabilir Kültür Varlıklarını Koruma ve Onarım Bölümü tarafından gerçekleştirilmiştir. Buna yönelik uygulamalarda toplamda 564 adet aydınlatma armatürü temizlenmiş, belgelenmiş; depolanan aydınlatma armatürlerinin türü, sayısı, tarihi eser niteliği, hasar durumu tespiti, onarım ve yerinde montajı hakkında önerileri içeren ayrıntılı bir rapor hazırlanmıştır. Ayrıca, montaj işlerini kolaylaştırmak için, bina kat planları üzerine ait oldukları yerler işaretlenerek, envanter numaraları yazılmıştır. 29 Nisan 2015 - 27 Mayıs 2015 tarihleri arasında gerçekleştirilen çalışmalar sonrasında, aydınlatma armatürlerinin paketlendiği 161 adet kutu ilgili birime teslim edilmiştir. Rektörlük Merkez Binası'nın eser niteliğindeki avize ve aplikleri bakımonarımları yapıldıktan sonra yerlerine asılmıştır. Gerekli kontroller Bölümüz ve Rektörlük yetkililerinin ortak denetimleriyle gerçekleştirilmiştir. Bu makalede, bahsedilen kapsamlı çalışmanın aşamaları özetlenerek verilmektedir.

\section{Anahtar Kelimeler}

İstanbul Üniversitesi, Tarihi avize, Belgeleme, Restorasyon, Aplikler

\begin{abstract}
This study focuses on the documentation and repair of the chandeliers and wall lights that were dismounted and protected in closed storage areas at the garden of University Rectorate during the restoration work of the Rectorate Central Building. The investigation to determine the required processes for the repair of these light fixtures was conducted by the Department of Conservation and Restoration of Artefacts, Faculty of Letters, Istanbul University. In the initial part of the study, 564 pieces of light fixtures were separately documented and reported, detailing the types, number, nature and value as historical artifacts, possible damages, repair and mounting of the stored light fixtures. Additionally, in order to facilitate the mounting-related works, the locations of these fixtures were marked on the building's floor plan, and their inventory numbers were recorded. Following the works that were carried out between April 29, 2015 and May 27, 2015, 161 boxes in which light fixtures had been packed were delivered to the related department. These historical artifacts were hung in their original places after they had been repaired. The required controls were conducted under the supervision of our Department and Rectorate staff. This study provides a summary of this comprehensive work.
\end{abstract}

\section{Keywords}

Istanbul University, Historical chandelier, Documentation, Restoration, Wall Lights

* Sorumlu Yazar: Işıl Özsait Kocabaş (Doç. Dr.), İstanbul Üniversitesi, Edebiyat Fakültesi, Taşınabilir Kültür Varlıklarını Koruma ve Onarım Bölümü, İstanbul, Türkiye. E-posta: isilozsait@gmail.com ORCID: 0000-0002-1926-0764

** Gülder Emre (Doç. Dr.), İstanbul Üniversitesi, Edebiyat Fakültesi, Taşınabilir Kültür Varlıklarını Koruma ve Onarım Bölümü, İstanbul, Türkiye. E-posta: gulderemre@gmail.com ORCID: 0000-0002-6730-0548

Atıf: Ozsait-Kocabas, Isil ve Emre, Gulder. "İstanbul Üniversitesi Rektörlüğü Merkez Binası Avize ve Apliklerinin Restorasyon Öncesi Belgeleme Çalışmaları ve Onarım Önerileri." Art-Sanat, 13 (2020): 335-360.

https://doi.org/10.26650/artsanat.2020.13.0014 


\section{Extended Summary}

The restoration of Istanbul University's (I.U.) historic Rectorate Central Building took place between 2009 and 2015, within the scope of the I.U. Renovation and Restoration Projects. During this period, the chandeliers and wall lights of the building were dismounted and stored in the containers that were placed in the Rectorate's garden, to be mounted back in their original places following the completion of the renovation and restoration process. For the restoration works for these chandeliers and wall lights, which are an integral part of the historic building, a report and technical specifications were requested from the Department of Conservation and Restoration of Artefacts, Faculty of Letters, Istanbul University. In line with this request, documentation and damage assessment were conducted by the Department between April 29, 2015 and May 27, 2015. As a result, 245 chandeliers, 14 lanterns, 2 lamp shades, 4 floor lamps, 294 wall lights stored in containers and 1 chandelier and 1 lantern were all designated with an inventory number, and also 1 crystal chandelier that was being repaired in Room Z-16 and 2 tulip chandeliers that were in Room Z-15 of the building were recorded. The types, specifications, general sizes and value as artifacts of these light fixtures were determined and defined, and suggestions for their repair were proposed according to their determined current state. In addition to the prepared report, the inventory and box list with respect to the floor plans; the simplified list that indicates types, numbers and value as historical artifact, which will make easier the defining process in the movable record control system; the floor plans that show the places/spots where the chandeliers and wall lights were to be mounted; and an additional file and photograph folder that includes the inventory files, which serves as identity cards for artifacts, were prepared.

Within the scope of documentation works, the lighting fixtures in boxes were taken out, cleaned and grouped among themselves with chandeliers and wall lights of similar type. Thanks to the hanging system that was constituted, the disassembled parts of each light fixture were reassembled to the best extent possible, and their general appearance, components and the number of components were determined. During photography works, general and close-up scaled photographs of the chandeliers and wall lights were taken in three different directions. A simple sketch of each chandelier and wall light type was drawn; their width, length and depth sizes were provided on the sketches; details such as their shapes, types, materials of manufacture, bell glasses, state of deterioration, missing parts, fractures and cracks, the ability of the main frame to support itself were defined; and suggestions for their repair were proposed. In order to make easier their documentation and the determination of their state of damage, the light fixtures were grouped by being named according their type of design. As a result, 11 different groups, including tulip, candelabrum, star, crystal, special group (with branches, blue, with coal gas, Murano-rose glass, with brass branches, green and small brass chandeliers), lanterns, drops, wooden, diffuser, small-sized crystal-glass, 
and others lamps were defined. In this study, among these groups, the states of the chandeliers of historical value that must definitely be put back in their places and proposals towards this purpose are described. As a result of the evaluations made, of the 11 groups of light fixtures, chandeliers, wall lights and lanterns that are in tulip, candelabrum, star, crystal, and special groups were determined to have historical value. Since the chandeliers and wall lights handled as historical artifacts are found in a building that was constructed in the second half of the 19th century and that is treated as a historical building, and are complementary decorative elements that cannot be considered separate from the architecture and hand-carved works in that building, they are considered to be antiquities and historical heritage worthy of documenting. These light fixtures exemplify the types of light fixtures of their period and reveal the change in lighting technologies witnessed since then, including the transition from coal gas to electricity. Furthermore, they are highly aesthetic with their glorious design and the elaborate work on them.

The state of the chandeliers and wall lights of historical value are quite good, excluding the crystal group. There is very little damage on the pedestals and bodies with the bearing function. Some arms have become either too close or far apart due to distortion, and some are hanging loose due to the fitting screws either becoming loose or getting lost. Some elements have slightly come loose. Some other elements are either broken or disconnected. There are fractures and cracks on the bell glasses. The connection metals of crystals that are decorative ornaments have mostly corroded and are loose on joints, with some broken off. There is corrosion, blackening on the body and arms, and rust/oxidation on the screws. Fixing of distorted arms, brazing of small fractures on the brass arms, tightening of loose parts would just be sufficient for most of the chandeliers and wall lights. Though there are not many fractures on the main arms of the crystal chandeliers, there are quite many broken pieces on the thin arms, crystal stick ornaments, crystal plates and other crystal parts. For the repair of the crystals, it has been suggested that importance be given to the adhesion of the broken pieces and that the missing parts be completed in accordance with their original following the adhesion process.

As a result, the lighting fixtures (tulip, candelabrum star, crystal, special group and lanterns) that were found in the ground, first and second floors of Block B, which constitute the historical and original section of the central building, and the ones in the ground floor Room Z-51 and first floor Rooms 1K-39, 1K-53, 1K-10, 1K-23, and $1 \mathrm{~K}-09 \mathrm{~A}, 1 \mathrm{~K}-05,1 \mathrm{~K}-58$ of the other blocks were hung back in their places following the end of the repair by the required procedure for historical artifacts. 


\section{Giriş}

İstanbul Üniversitesi Tarihi Rektörlük Merkez Binasının restorasyonu, İ.Ü. Yenileme ve Restorasyon Projeleri kapsamında, 2009-2015 yılları arasında sürdürülmüştür. ${ }^{1}$ Bu süreç sırasında yerinden sökülmüş olan avize ve aplikler, rektörlük bahçesindeki konteynerlarda depolanmıştır. Uygulamaların son yılında, tarihi binanın bütünleyici bir parçası olan avize ve apliklerin restorasyonu için bakım-onarım ihalesi hazırlıkları gerçekleştirilmiştir. Bu doğrultuda, aydınlatma armatürlerinin fotoğraflanması, taşınır kayıt kontrol sisteminde tanımlanacak şekilde türü, sayısı, tarihi eser niteliği taşıyıp taşımadığı ve hasar durumunu belirtir bir listenin oluşturulması; onarım yapılma şekli, onarım sonrasında takılacak yerlerin belirlenmesi ve takılma şekilleri konularını içeren bir rapor ve teknik şartnamenin hazırlanması İ.Ü. Edebiyat Fakültesi Taşınabilir Kültür Varlıklarını Koruma ve Onarım Bölümü’nden istenmiștir. Buna yönelik olarak, uzmanlık alanlarına göre Taşınabilir Kültür Varlıklarını Koruma ve Onarım Bölümü öğretim üyelerinden Doç. Dr. Iş1 Özsait Kocabaş ve Doç. Dr. Gülder Emre başkanl1ğında, Arkeolog Mehmet Sağır ve öğrencilerden oluşan 25 kişilik bir ekip oluşturulmuştur. Ön değerlendirmeler, İ.Ü. Yapı İşleri ve Teknik Daire Başkanlığı'ndan Elk. Elkn. Müh. Abdurrahman İçyüz ve Elk. Tek. Burhan Yalçın'la yapılmış ve çalışmalar rektörlük bahçesindeki avize depolarının, Elk. Elkn. Müh. Abdurrahman İçyüz tarafindan açılmasıyla, 29 Nisan 2015 tarihinde başlamıştır.

Depodaki 245 adet avize, 14 adet fener, 2 adet abajur, 4 adet yer lambasi ve 294 adet aplik ve Merkez bina içinde bulunan 1 adet avize, 1 adet fenerin her birine envanter numarası verilmiş; ayrıca Z-16 numaralı odadaki 1 adet kristal avize ve Z-15 numaralı odadaki 2 adet lale avize kayıtlara geçirilmiştir. Hazırlanan 85 sayfalık rapora ilaveten, çalışma sonuçları, katlara göre hazırlanmış envanter ve kutu numaraları listesi, taşınır kayıt kontrol sisteminde tanımlanmayı kolaylaştıracak tip, sayı, eser niteliğini gösteren sadeleştirilmiş liste, eser niteliğindeki avize ve apliklerin takılacağ 1 yerlerin işaretlendiği kat planları, her bir eserin kimliğini oluşturan envanter kayıtlarından oluşan 161 sayfalık ek dosya ve fotoğraf klasörü (CD halinde) hazırlanmıştır. Depodaki çalışmalar tüm avize ve aplik kutularının açılıp değerlendirilmesi ve tekrardan paketlenmesi sonucu 27 Mayıs 2015 tarihinde tamamlanmıştır.

\section{Yüzyılda Aydınlatma ve İstanbul Üniversitesi Rektörlük Merkez Binası Avizeleri}

Eski dönemlerde, mumlar, kandiller ve fenerlerle gerçekleştirilen aydınlatma, 18. yüzyılda Sanayi Devrimi'yle birlikte farklı bir ivme kazanmıştır. Teknolojinin gelişmesiyle birlikte, sanayinin ilerlemesinde önemli bir etken olan 1şıklandırma sorunu, 19. yüzyılın başında, devrimin başladığı yer olan İngiltere'de hava gazı aydınlatmasıyla çözüme ulaşmış; fabrikalarda ardından sokaklar ve konutlarda gazlı aydınlatma-

1 Bu çalışma, İstanbul Üniversitesi Rektörlüğünün izin ve katkılarıyla gerçekleştirilmiştir. 
ya geçilmiştir. ${ }^{2}$ Batıdaki gelişmeler doğrultusunda, Osmanlı İmparatorluğu'nda ilk kez 1839 yılında Tanzimat Fermanı sonrasında sokakların düzenli olarak ışıklandırılma çalışmaları başlamıştır. ${ }^{3}$ 1850'li yılların başından itibaren, saraylar ve yönetime ait yapıların hava gazı sistemiyle aydınlatıldığı görülmektedir. ${ }^{4}$ Bu konudaki ilk tesisler, Dolmabahçe Sarayı için 1853 yılında inşa edilen Dolmabahçe Gazhanesi ve 1865 yılında Beylerbeyi Sarayı için kurulan Kuzguncuk Gazhanesi'dir. ${ }^{5}$ Başka gazhanelerin de faaliyete geçmesiyle birlikte, 19. yüzyılda hava gazı, İstanbul sokaklarının ve konutların 1şıklandırılmasında kullanılır hâle gelmiştir. İstanbul'da elektrikle ilgili ilk girişimler, bu yüzyılın sonlarına doğru sokakların aydınlatılması üzerine yapılmıştır. Yıldız sarayı, elektrik motoruyla çalışan şamdanlarla aydınlatılan ilk yapıdır. ${ }^{6}$ Ardından gelen yıllarda, elektrik motorlarıyla bazı konutların ve askeri gemilerin aydınlatıldığı bilinmektedir. ${ }^{7}$ Osmanlı Devleti'nin ilk elektrik üretimi 1902 yılında Tarsus'ta inşa edilen hidroelektrik santraliyle gerçekleştirilmiştir. ${ }^{8}$ İstanbul'da elektrikle aydınlatmaysa 1910 y1lında Macar Ganz Anonim Elektrik Şirketi'nin 50 yıl süreyle İstanbul'un elektrik dağıtım imtiyazını almasıyla başlamıştır. Bunu takiben Silahtarağa Elektrik Santrali inşa edilerek 1914 yılında işletmeye açılmıştır. Üretilen elektrik öncelikle tramvay hatlarının ve Dolmabahçe Sarayı'nın elektrik enerjisinin sağlanmasında kullanılmıştır. ${ }^{9}$

Bu yıllarda, Batılılaşma hareketleri etkisiyle saraylar için Avrupa'dan ithal edilen hava gazıyla çalışan avize ve şamdanlar, elektrikle çalışabilecek şekle dönüştürülmüştür. ${ }^{10}$ Dolmabahçe Sarayı'nın 1910-1912 yılları arasında Mimar Vedat Bey tarafindan gerçekleştirilen onarımlarında Saraya elektrik sistemi eklenerek yeni düzenlemeler yapılmış; hava gazıyla çalışan aydınlatma elemanlarına, elektrik tesisatı adapte edil-

2 Nazmiye Özdemir, “İmparatorluktan Cumhuriyet'e Türkiye'de Elektriğin Tarihsel Gelişimi (1850-1938)," Osmanlı Medeniyeti Araştırmaları Dergisi 2.3 (2016), 18.

3 Asu Aksoy, Funda Açıkbaş ve Ayşenur Akman, “Silahtarağa Elektrik Santralı’nın Hikayesi," Silahtarağa Elektrik Santralı 1910-2004, haz. Asu Aksoy (İstanbul: İstanbul Bilgi Üniversitesi Yayınları, 2009), 13.

4 Güller Karahüseyin, Milli Saraylar Aydınlatma Araçları Koleksiyonu (İstanbul: TBMM Milli Saraylar, 1998), 7.

5 Özdemir, “İmparatorluktan Cumhuriyet’e Türkiye'de Elektriğin Tarihsel Gelişimi (1850-1938)," 20; Mehmet Mazak, “Anadolu Yakasının İlk Sanayi Tesislerinden Kuzguncuk Gazhanesi ve Üsküdar," IV. Üsküdar Seтроzуити 3-5 Kasım 2006 Bildirileri 1 (2007), 179; Tuncay Cengiz Göncü, "Beylerbeyi Sarayı'nın İnşa Süreci, Teşkilâtı ve Kullanımı” (Yüksek Lisans Tezi, İstanbul Üniversitesi, 2006), 115.

6 Adnan Dinçel, “Türkiye'de Elektriğin İlkleri Silahtarağa Santralistanbul," Kaynak Elektrik Dergisi Ağustos 2007 (2007), 61; Güller Karahüseyin, Shedding Light on an Era: The Collection of Lighting Appliances in 19th Century Ottoman Palaces (İstanbul: TBMM Milli Saraylar, 2009), 30.

7 Vahdettin Engin ve Ufuk Gülsoy, Osmanlı'dan Cumhuriyet'e İstanbul'da Elektrik (İstanbul: İETT Yayınları, 2016), 148.

8 Özdemir, “İmparatorluktan Cumhuriyet’e Türkiye'de Elektriğin Tarihsel Gelişimi (1850-1938),” 21.

9 Aksoy, Açıkbaş, Akman, "Silahtarağa Elektrik Santralı’nın Hikâyesi,” 3; Dinçel, “Türkiye'de Elektriğin İlkleri Silahtarağa Santralistanbul," 62.

10 Tuncay Cengiz Göncü, “Dolmabahçe Sarayı'nın İnşa Süreci, Mekân ve Teşkilat” (Doktora tezi, İstanbul Üniversitesi, 2015), 178, 306; Karahüseyin, Milli Saraylar Aydınlatma Araçları Koleksiyonu, 12-13; Önder Küçükerman, "Dolmabahçe Sarayı ve Ünlü Kristalleri," Skylife Kasım 1997 (1997), 50; Cengiz Can, “İstanbul'da 19. Yüzyıl Batılı Levanten Mimarların Yapıları ve Koruma Sorunları" (Doktora tezi, Yıldız Teknik Üniversitesi, 1993), 37, 41-42. 
miştir. ${ }^{11}$ Aynı şekilde, 1909 yılında Beylerbeyi Sarayı'nın, tefriş edilmesi ve sarayın aydınlatma düzenlemesi işi saray baş mimarı Vedat Tek gözetiminde yapılmıştır. ${ }^{12}$ Bu dönemde, saraylarda bulunan aydınlatma armatürlerinin İtalya, İngiltere, Fransa, Çekoslovakya gibi ülkelerden gelen Murano camları, Bohemya, Baccarat ve İngiliz kristallerinden yapılmış ihtişamlı avize ve aplikler oldukları, tavan lambaları ve fenerlerin küçük odalar ve koridorlarda kullanıldığı çeşitli kaynaklarda geçmektedir. ${ }^{13}$

İstanbul Üniversitesi Rektörlük Merkez Binası, İstanbul'daki ilk Osmanlı sarayı olan Eski Saray'ın arazisinde, Fransız mimar Bourgeois tarafından 1865-1866 yıllarında inşa edilmiş̧ir. Seraskerlik makamı olarak inşa edilen kâgir bina bir süre bu amaçla Harbiye Nezareti olarak kullanılmış, 1923 yılında Darülfünun'a tahsis edilmiştir. Bu kurumun devamı olan İstanbul Üniversitesi, 1933 yılında Türkiye'nin ilk üniversitesi olarak öğretime başlamıştır. ${ }^{14}$

İstanbul Üniversitesi Rektörlük Merkez Binası, tarihi öneminin yanı sıra estetik özellikleriyle de dikkate değerdir. Dikdörtgen planlı ve üç katlı olan bina, birden çok üslubun bir arada kullanıldığı eklektik tarzda yapılmıştır. Karşılıklı yönlerinde simetrik oluşumlu, yalın bir düzenlemeye sahip olan cepheler Neo-Rönesans Dönemi özelliklerini yansıtmaktadır. Binanın ana girişi güney cephesindedir. Yapı orta avlulu plana sahiptir. Zemin katın ortasındaki kuzey-güney doğrultulu dikdörtgen avlunun, doğu ve batı yönlerindeki merdivenlerinden üst katlara çıkılmaktadır. ${ }^{15}$ Mermer sütunlar, taş işlemeciliği, duvar ve tavanlardaki kalem işleri iç dekorasyonun etkileyici karakteristiklerindendir. Duvar ve tavan süslemelerinde çeşitli renklerin ve sarı yaldızın kullanıldığg renkli iç tasarım, rûmi ve bitkisel motifler, yumurta ve diş frizleri, geometrik ve özellikle yıldız biçimli çıtalı tavan motifleriyle bezenmiştir. Bunun yanı sıra bazı odalarda üç boyutlu kıvrımlı bitkisel figürler ve istiridye motifleri görülmektedir. İç mekânlardaki zengin süslemeler ve tasarım özellikleri ağırlıklı olarak Oryantalist ve kısmen Barok üsluplarıyla ilişkilendirilmiştir. ${ }^{16}$ Binanın iç mimarisi ve tavan süslemeleriyle bütünleşen avize ve aplikleri, yukarıda anlatılan aydınlatma teknolojisi tarihinin hâlen yaşayan ünik kanıtlarını bize sunmaktadır. Muhteşem güzellik ve incelikte tasarlanmış avizeleri, görselliklerinin yanı sıra, hava gazından

11 Deniz Güner, “Akaretler Sıra Evleri: Bir Multigrafik Okuma Denemesi,” Dolmabahçe: Mekânın Hafizası, haz. Bahar Kaya (İstanbul: İstanbul Bilgi Üniversitesi Yayınları, 2005), 234; Küçükerman, "Dolmabahçe Sarayı ve Ünlü Kristalleri,” 60.

12 Göncü, "Beylerbeyi Sarayı’nın İnşa Süreci, Teşkilâtı ve Kullanımı,” 94.

13 Karahüseyin, Milli Saraylar Aydınlatma Araçları Koleksiyonu, 12-13; Küçükerman, "Dolmabahçe Sarayı ve Ünlü Kristalleri," 49-50; Çelik Gülersoy, "Dolmabahçe Sarayı,” Skylife. Haziran 1994 (1994), 47.

14 Feza Günergun ve Sevtap Kadığlu, “İstanbul Üniversitesi’nin Yerleşim Tarihi Üzerine Notlar,” Osmanlı Bilimi Araştırmaları 8.1 (2006), 140-142; Cengiz Can, "Harbiye Nezareti Binası," Dünden Bugüne İstanbul Ansiklopedisi, c. 3 (İstanbul: Tarih Vakfı Yayınları, 1994), 550-551.

15 Akın Tuncer, "Osmanlı Seraskeri Binası ve Seraskeri Köşkleri Dekorasyonu Üzerine Bir Araştırma” (Yüksek Lisans Tezi, Mimar Sinan Güzel Sanatlar Üniversitesi, 2005), 49, 52-54; Can, "Harbiye Nezareti Binas1," 551.

16 Tuncer, “Osmanlı Seraskeri Binası ve Seraskeri Köşkleri Dekorasyonu Üzerine Bir Araştırma,” 225-230. 
elektriğe geçiş dönemindeki teknolojik gelişimin aşamalarını ve Osmanlı Dönemi’nin ilk elektrik tesisatlarının örneklerini sergilemektedir.

\section{Belgeleme Çalışmaları}

Avize ve aplikler, uzun konteynerlarda, büyük karton kutular ve ahşap kasalar içinde, depolanmış hâlde teslim alınmıştır. Çalışmalar, bunların içinde ve önündeki açık alanda gerçekleştirilmiştir. Mekânın darlığı ve kutuların ağırlığı nedeniyle, öncelikle taşınabilen küçük kutular konteyner dışına çıkartılmış; daha ağır kutular konteyner içinde açılmıştır. Kutulardan çıkarılan aydınlatma armatürleri temizlenmiş; benzer tipteki avize ve aplikler kendi içlerinde gruplanmıştır. Daha sonra, armatürlerin sökülmüş olan parçaları mümkün olduğunca birleştirilmiş; oluşturulan asma sistemi sayesinde, her bir avizenin genel görünüşü, hangi elemanlardan oluştuğu ve bunların sayısı belirlenmiştir (G. 1a-b). Avize ve apliklere, asılacakları odanın katı ile tasarım tipini gösteren kısaltma ve sıra sayısından oluşan birer envanter numarası verilmiş; bu numara etiketlere yazılarak üstlerine bağlanmıştır. Aynı zamanda, bu numaralar fotoğraf çekiminde ve tanımlama listelerinde kullanılmış, bu sayede her birinin kimlik kartı oluşturulmuştur (G. 1c). Avize ve apliklerin yerlerini belirlerken mevcut fotoğraflardan yararlanılmış, Rektörlük Merkez Binası gezilerek odalardaki avize ve aplik sayıları ve konumları belirlenmiş, mevcut avize ve aplik sayısı ile kontrol edilmiştir.
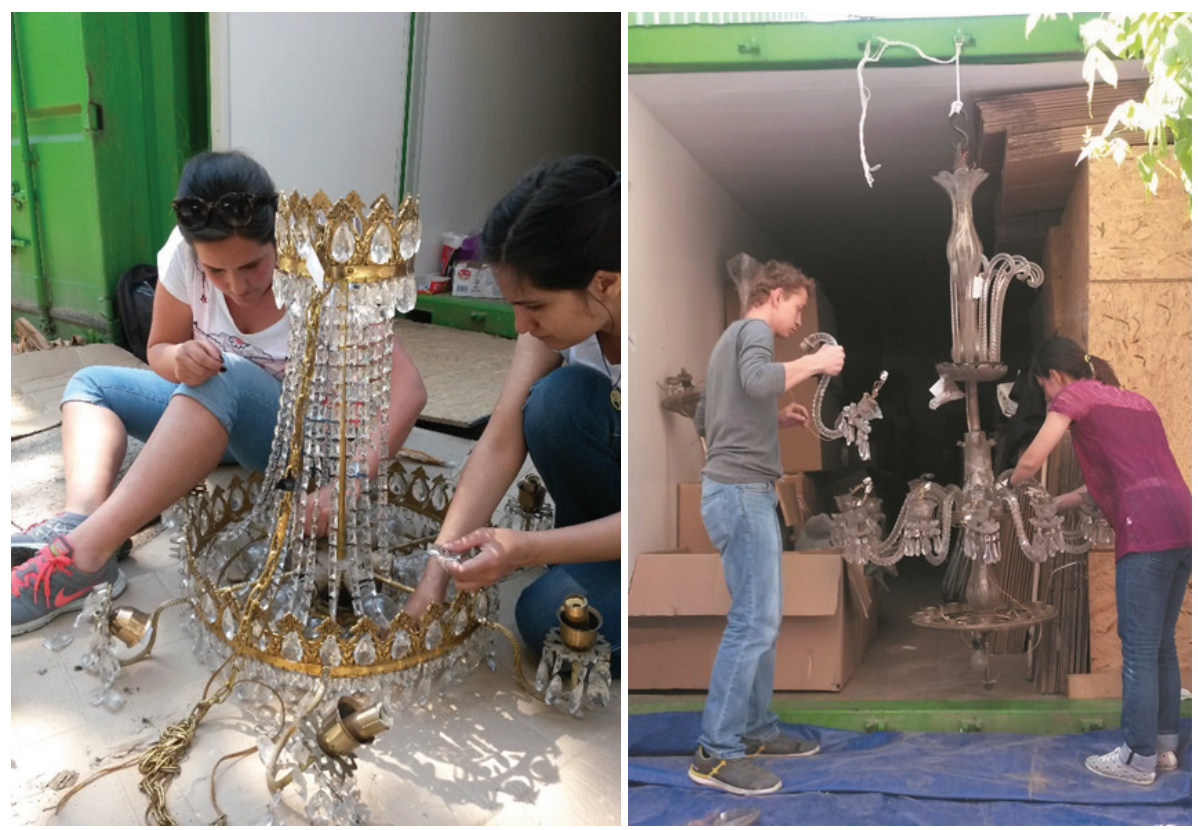

G. 1a-b. Avize elemanlarının birleştirilmesi (I. Özsait Kocabaş, 2015) 


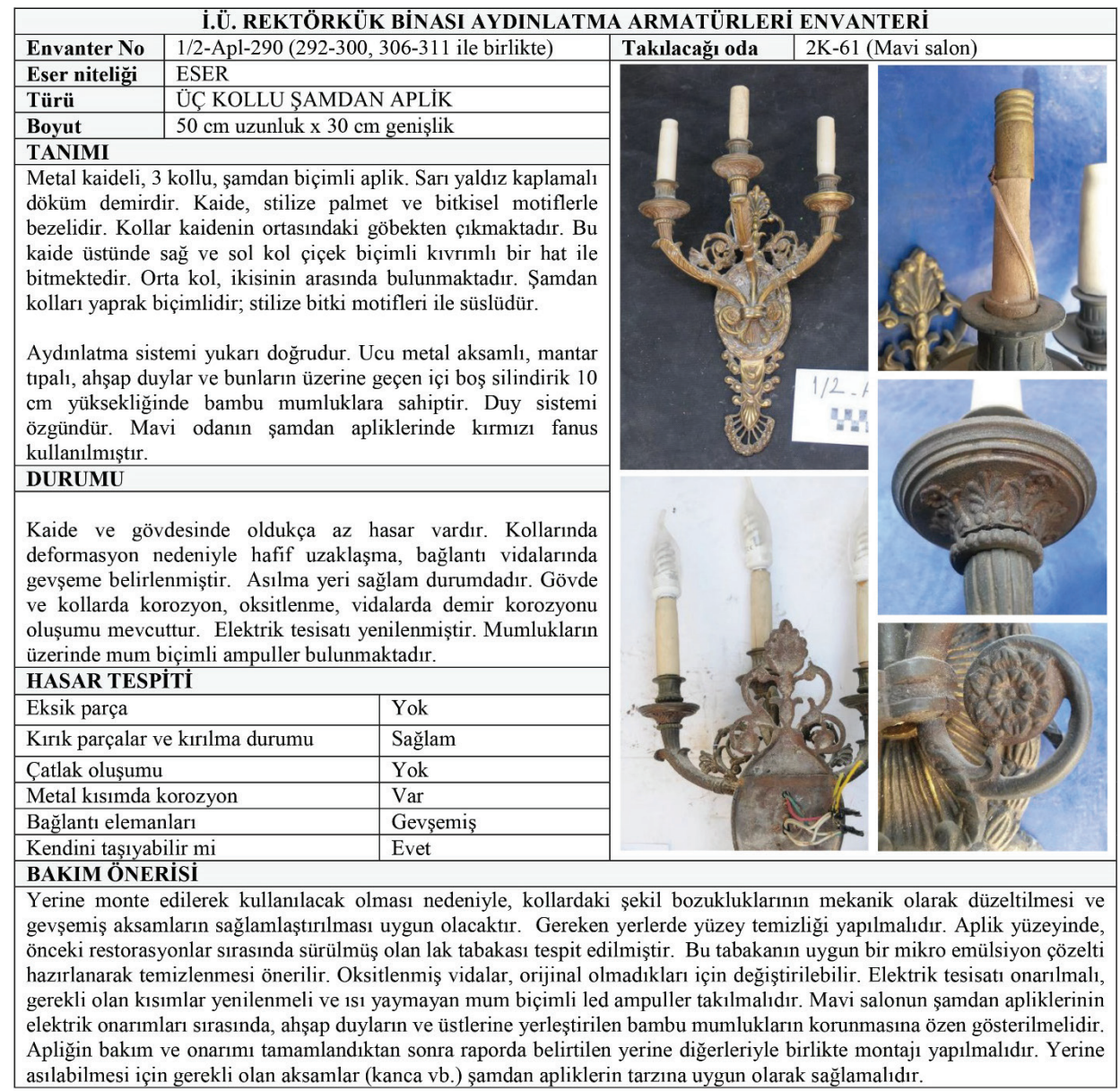

G. 1c. Aydınlatma armatürleri envanter fişi örneği (I. Özsait Kocabaş, 2015)

Fotoğraflama çalışmalarında, avize ve apliklerin üç yönünden, genel ve detay fotoğrafları ölçek konularak çekilmiş ve arşivlenmiştir. Fotoğraf klasörlerine bulundukları kutu numarası ve asılacağı odanın adı yazılmıştır. Ayrıca, avize ve apliklerin basit bir krokisi çizilmiş (G. 2); bu kroki üzerinde genişlik, uzunluk ve derinlik ölçüleri verilmiş; biçimsel özellikleri, tipleri, imal edildiği malzeme, fanusları gibi detaylar; üzerlerindeki bozulma durumu, eksik kısımları, çatlak ve kırıkları, ana iskeletin kendini taşıyabilme durumu ve bakım-onarım önerileri tanımlanmıştır. Aydınlatma armatürleri, belgeleme ve değerlendirme çalışmaları tamamlandıktan sonra, asitsiz kâğıt koruyucularla sarılarak yeni karton kutulara yerleştirilmiş, araları desteklenerek paketlenmiştir. Kutuların üzerine, içinde bulunan avizenin envanter numarası, hangi parçalarının bulunduğu, sağlamlık durumu ve asılacağı odanın numarası yazılmıştır. 


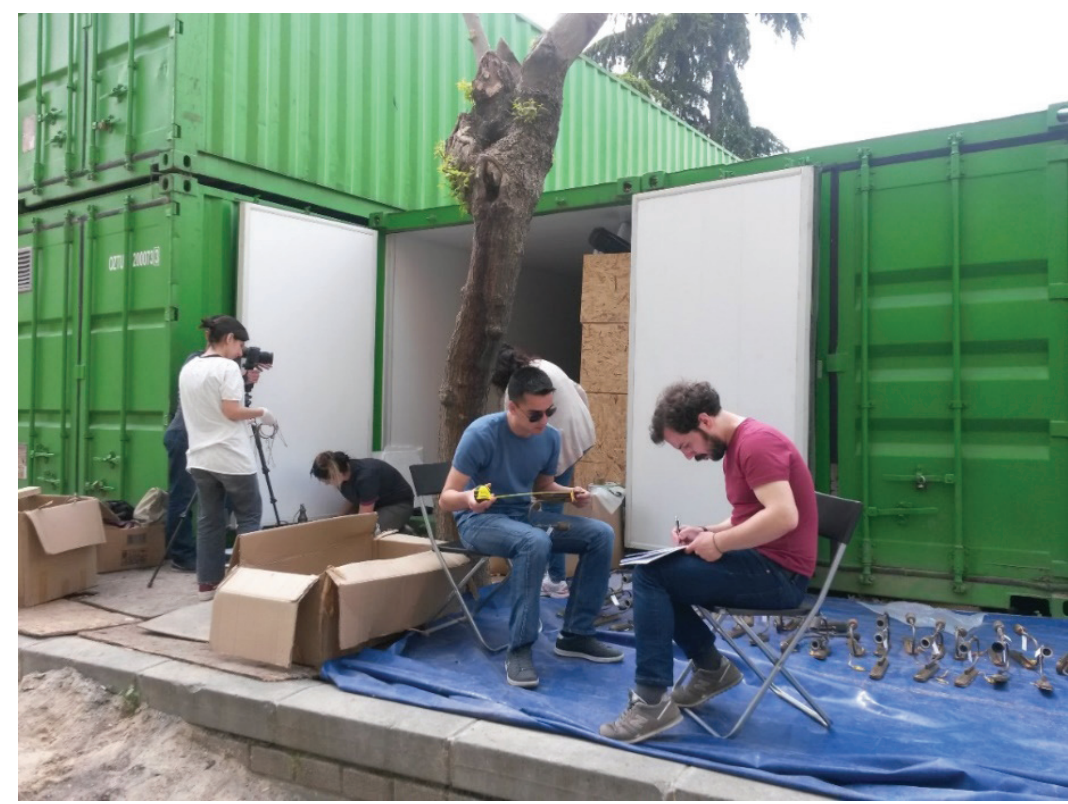

G. 2. Fotoğraf ve çizim çalışması (I. Özsait Kocabaş, 2015)

\section{Aydınlatma Armatürlerinin Grupları ve Onarım Önerileri}

Aydınlatma armatürleri, belgelemeyi ve hasar durumunu belirlemeyi kolaylaştırmak için tasarım tiplerine göre isimlendirilerek gruplandırılmıştır. Buna göre, lale, şamdan, yıldız, kristal, özel grup (dal, mavi, hava gazlı, Murano-gül fanuslu, pirinç dallı, yeşil ve küçük pirinç avizeler), fener, damla, ahşap, glop, küçük boy kristal-cam ve diğer (uzun avize, küre fanuslu, abajurlar ve yer lambaları) olarak 11 farklı grup oluşturulmuştur. Her grup kendi içinde avize ve aplik olarak ayrılmıştır. Bu gruplar arasında, yerine kesinlikle takılması gerekli olan tarihi eser niteliğindeki avizelerin durumları ve buna yönelik öneriler aşağıda açıklanmıştır.

\section{Lale Grubu}

Bu aydınlatma grubu birbirinin aynı 4 adet iki katlı avize, 2 adet iki katlı büyük aplik (paraçol) ve 55 adet üç kollu aplikten oluşmaktadır. Ağırlıklı olarak pirinç malzemeden yapılmıştır. Avize ve apliklerin görünmeyen kısımlarındaki taşıyıcı aksamlarında demir konstrüksiyon kullanılmıştır. Bu grup fanussuz tasarlanmıştır. Elektrik tesisatları kolları oluşturan boruların içinden geçmektedir. Lalelerin içindeki modern ampul duylarının yakın dönem onarımlarında takıldığı belirlenmiştir. Lale avizeler, güney ve kuzey cepheleri giriş holleri ve B blok merdiven boşluklarında; lale aplikler, güney ve kuzey cepheleri giriş holleri, B blok merdiven boşlukları yan duvarlar, B blok birinci kat ve ikinci kat koridorlarında (1K-61, 62 ve 2K-62, 63); iki katlı aplikler (paraçollar), B blok merdiven boşluklarında asılıdır (G. 3). 


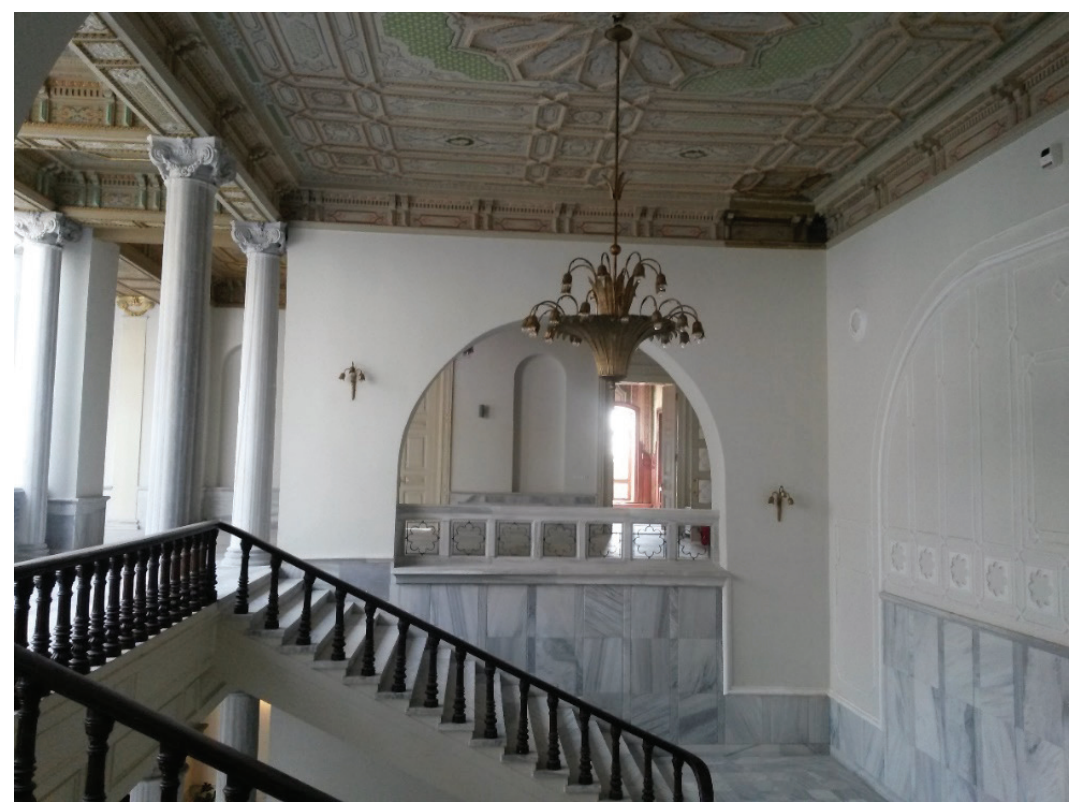

G. 3. B blok merdiven boşluğunda bulunan lale grubu avize ve aplikler (I. Özsait Kocabaş, 2015)

Lale avize (Z-LALE-AV-265, 266): Toplam uzunluğu yaklaşık 2,97 m olan avize, altta yaklaşık 1,10 m çapında büyük, üstte $27,5 \mathrm{~cm}$ çapında daha küçük yapraklardan meydana gelmiş birer göbekten oluşmaktadır. Bu göbeklerden aşağı sarkan dallar şeklinde tasarlanan boruların ucunda birer lale bulunmaktadır. Dal biçimli kollar alt katta 14 adet, üst katta 10 adettir.

Lale aplik (1-LALE-APL 86-112; 238-250, 401; 2-LALE-APL 1-11, 15, 113): Yapraklı bir formla alt kısımdan başlayıp ters dönmüş üç laleyle biten üç kollu aplikler, yaklaşık $55 \mathrm{~cm}$ uzunluğunda, $30 \mathrm{~cm}$ genişliğinde ve $22 \mathrm{~cm}$ kalınlığındadır. İki katlı büyük aplikler (paraçollar) yaklaşık $89 \mathrm{~cm}$ uzunluğunda, $65 \mathrm{~cm}$ genişliğindedir. Alt tarafta yaprak bezemeli çanaktan çıkan beş adet kol ve yapraklarda şekillendirilmiş kaidenin arkasında birleşen altı adet üst kolla bunların ucundan aşağı bakan lalelerden oluşmaktadır.

Aplikler genelde sağlam ve kendilerini taşıyabilecek durumdadır. Yüzeylerinde kararma ve seyrek karıncalanma (küçük oyuk) belirlenmiştir. Eski yıllardaki boya badana işlerinde sökülmeyen bazı aplikler üzerine sıçrayan boya tabakaları mevcuttur. Arka taraflarında kabloların girdiği boru uçlarında yoğun oksitlenme tespit edilmiştir (G. 4a). Gerekli yüzey temizliği polisaj yoluyla yapılmalıdır. Kollarındaki eğilme ve deformasyon mekanik işlemlerle düzeltilmelidir. Bağlantı yerleri sağlamlaştırılmalı, oksitlenmiş vidalar orijinal olmadığ 1 için değiştirilmeli, taşıyıcı özelliği nedeniyle kırıklar sarı kaynakla kaynaklanmalıdır. Aplik ve avizelerin üzerlerindeki değişik biçim ve büyüklükteki vidalardan farklı zamanlarda onarım gördükleri anlaşılmaktadır 
(G. 4b). Bu vidaların aslına uygun şekilde yenilenmesi tavsiye edilmiştir. Sökülerek büyük ahşap kasalar içinde depolanmış olan avizelerin taşıyıcı aksamları sağlamdır. Pirinç malzemeden yapıldıkları için kararma şeklinde oksitlenme görülmektedir. Yerinden çıkmış pirinç elemanlar tekrar vidalanmalı; yaprak uçlarında belirlenen küçük kırıklar sarı kaynakla kaynaklanmalıdır. Avize ve paraçolların taşıyıcı parçalarında galvanik bozulma ve yoğun demir korozyonu belirlenmiştir (G. 4c). Bu kısımlarda dişçi motoru ve gri renkli tel firça ile mekanik temizlik yapılmalı, tannik asitle korozyonu stabilize ederek üzerinde koruyucu bir film tabakası oluşması sağlanmalıdır. ${ }^{17}$
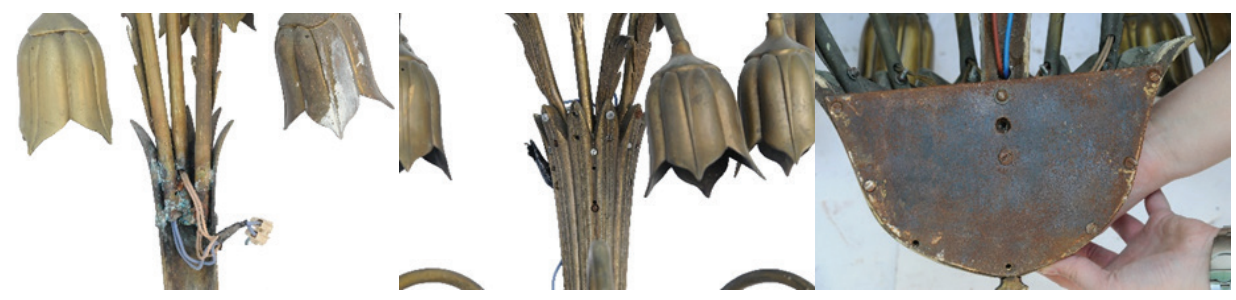

G. 4. Lale grubu apliklerde bozulma durumu; a) boru uçlarındaki oksitlenme ve lale kısmında boya kalıntısı (solda), b) aplik gövdesinde farklı boyutlardaki vidalar ve korozyon oluşumu (ortada), c) paraçolun taşıyıcı parçasında demir korozyonu (sağda) (M. Sağır, 2015)

\section{Şamdan grubu}

Şamdan grubunda birbirinden farklı iki adet avize, 28 adet iki kollu, 103 adet üç kollu ve 4 adet tek kollu aplik belgelenmiştir. Avizeler pirinç, aplikler sarı yaldız kaplamalı döküm demirdir. Mavi odanın üç kollu aplikleri ve tek kollu aplikler dışında bu grupta fanus kullanılmamıştır. Elektrik tesisatları kolların içinden geçerek mumluklardan çıkmaktadır. Şamdan grubu avizeler birinci katta sekreter odası (1K-05) ve rektör danışmanı odasında (1K-10); üç kollu aplikler rektör sekreteri ve toplantı odaları (1K-01A ve 1-K-59A), kılıçlık (2K-01), doktora salonları (2-K292-K30 ve 2-K31), mavi salon ve yan odası (2K-60 ve $2 \mathrm{~K}-61$ ); iki kollu aplikler rektörlük makam odası (1-K-60); tek kollu aplikler Mevlana (2K-58) odasında asılıdır.

Şamdan avize: Küçük avize (1-Ş-AV 354) altı kolludur. Ana gövdeden yukarı doğru kıvrılan ince, yaprak biçimli kollarının ucunda eski tipte yıldız tabaklı mumlukları vardır. Bunların üzerinde modern ampul duyları bulunmaktadır. Çiçek biçimli rozetlerden oluşan üç zincir, üstte işlemeli bir plakaya bağlıdır. Asma zinciri özel olarak boğumlu yapılmıştır. Yaklaşık gövde uzunluğu $53 \mathrm{~cm}$, genişliği $73 \mathrm{~cm}$ 'dir. Orta boydaki diğer avize (1-Ş-AV 353), yukarı kıvrılan on iki kola sahiptir. Yaklaşık gövde uzunluğu $58 \mathrm{~cm}$, genişliği $82 \mathrm{~cm}$ 'dir. Yaprak biçimli kalın kolları ucunda, çiçek biçimli mumluk tabakları vardır. Elektrik tesisatı ucu metal aksamlı mantar tıpa ve ahşap aparatlıdır. Bunların üzerinde akmış mum görüntülü uzun plastik duylar takılmıştır. Asma zinciri ve rozans kapağı yaprak biçimlidir.

17 David Scott ve Gerhard Eggert, Iron and Steel in Art: Corrosion, Colorants, Conservation (England: Archetype Publications, 2009), 88. 

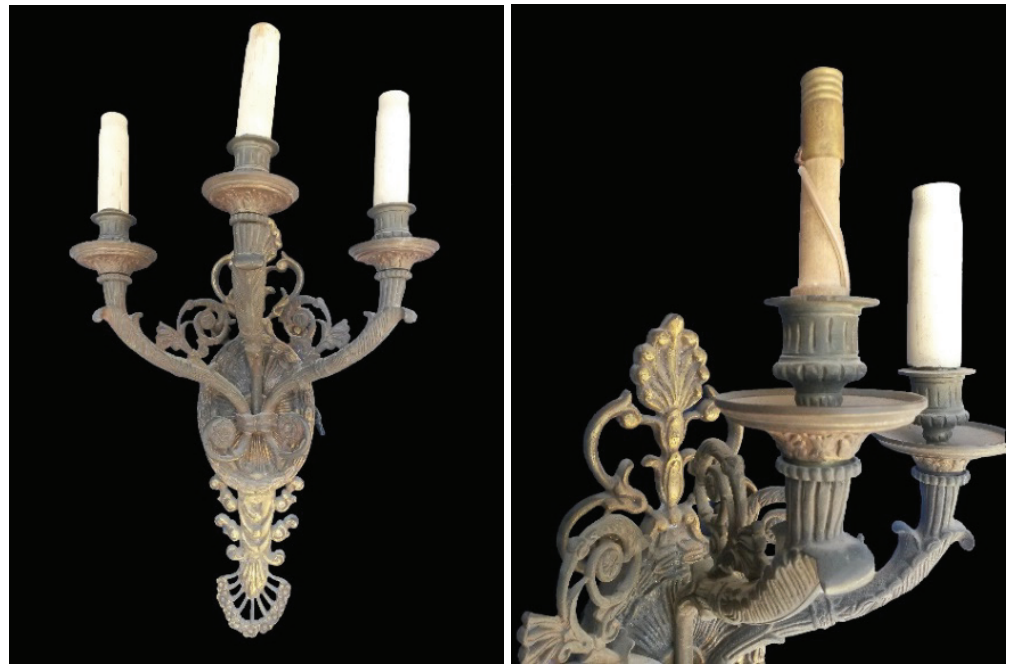

G. 5. Şamdan grubu 3 kollu aplik; a) genel görünüm (solda), b) mumluk detayı (sağda) (I. Özsait Kocabaş, 2015)

Şamdan aplik (2-MVL-APL 367-370; 1/2-APL 145-184, 267-337, 406-425): Şamdan biçimli gövdesi, mumluk boruları olan aplik tipidir. Tek, iki ve üç kollu çeşitleri vardır (G. 5a). İki ve üç kollu olanlar tarz olarak aynıdır. Stilize palmet ve bitkisel bezemeli kaideden çıkan yaprak biçimli ve stilize bitki motifleriyle süslü kollar yukarı doğru uzanmaktadır. Üç kollu şamdan aplikler, ucu metal aksamlı mantar tıpalı ahşap aparatlı duylara ve bunların üzerine geçen içi boş silindirik bambu mumluklara sahiptir (G. 5b). Bunların ucunda mum biçimli ampuller vardır. Üç kollu aplikler, yaklaşık $50 \mathrm{~cm}$ uzunluğunda, $30 \mathrm{~cm}$ genişliğindedir. Mavi odaya ait 16 adet üç kollu şamdan apliğin kırmızı fanusları vardır. İki kollu aplikler, zaman içinde yenilenmiş tesisata ve kısa mum biçimli plastik duylarla sahiptir. İki kollu aplikler yaklaşık $34 \mathrm{~cm}$ uzunluğunda, $27 \mathrm{~cm}$ genişliğindedir. Tekli olanların bezemeleri ve modeli farklıdır. $\mathrm{Bu}$ apliklerin eskileriyle uyumlu olarak yakın dönemde yaptırıldığı belirlenmiştir.

İki ve üç kollu apliklerin kollarında deformasyonlar nedeniyle kolların birbirine yakınlaşması ya da ayrılacak duruma gelmesi, bağlantı vidalarının gevşemesi ya da kaybolması sonucu sarkmalar tespit edilmiştir. Bazı elemanlar hafifçe yerlerinden oynamıştır. Gövde ve kollarda korozyon, oksitlenme, vidalarda demir korozyonu mevcuttur. Ancak kaide ve gövdelerinde oldukça az hasar vardır. Yerine monte edilerek kullanılacak olmaları nedeniyle, kollardaki şekil bozukluklarının mekanik olarak düzeltilmesi ve gevşemiş aksamların sağlamlaştırılması gereklidir. Bazı apliklerin yüzeylerinde önceki restorasyonlar sırasında sürülmüş olan lak tabakası hâlen durmaktadır. Bunların uygun bir mikro emülsiyon çözelti hazırlanarak temizlenmesi önerilmiștir. Gereken yerlerde yüzey temizliği ve bakımı yapılmalıdır. Ahşap duyları olan apliklerden bir kısmının bambu mumlukları kırılmış ya da kaybolmuştur. Onarımlar 
sırasında, bambu mumluklarının korunması; eksik ya da plastik olan mumlukların, aslına benzer biçim ve ölçülerde yaptırılarak takılması önerilmiştir. Şamdan avizeler sağlam ve tek parça halindedir. Özel tasarımlı askı zincirlerinin ve aksamlarının korunmasına dikkat edilmelidir. Avizeler, küçük mekanik onarımlar ve yüzey temizliği sonrasında yerlerine asılabilecek durumdadır.

\section{Yıldız grubu}

Y1ld1z grubunda, 2 adet birbirinin aynı tek katlı avize, tasarımları aynı boyutları farklı 6 adet avize, 18 adet aynı tip ve 2 adet farklı tipte aplik belgelenmiştir. Bu grup, pirinç kaide, kollar, çemberler ve stilize yıldız çiçeği biçiminde rozetlerden oluşmaktadır. Sarı metal çanaklar içindeki plastik mum içlikler üzerine sarı metal mumluklar geçmiştir. Elektrik tesisatı kolların içinden geçmektedir. Bu grubun özenli işçiliği, süslü zincirleri, bezemeli rozans kapakları ve küçük fanusları vardır. Fanuslar üzerinde kesme yıldız bezemesi bulunmaktadır. Yıldız avizeler zemin katta Z-51 numaralı odada, birinci katta rektör danışmanı (1K-23), genel sekreterlik (1K-39), rektör yardımcısı (1K-53) odalarında, senato toplantı salonu, bekleme odası ve hollerinde (1K-30 ve $1 \mathrm{~K}-331 \mathrm{~K}-32-\mathrm{A}$ ve $1 \mathrm{~K}-32 \mathrm{~A})$; aplikler rektör yardımcısı odasında (1K-53), senato toplantı salonu ve bekleme odasinda (1K-30 ve $1 \mathrm{~K}-33)$ asılıdır.

Yıldız avize: Tek katlı avizeler (YLZ-AV 205 ve 1-YLZ-AV 206), $51 \mathrm{~cm}$ çapında pirinç çemberin içinden geçerek yukarı kıvrılan altı adet pirinç kolun ucunda yıldız biçimli tabak ve bunların üzerinde içinde duyların bulunduğu kısa silindir çanaklardan oluşmaktadır. Kaidenin üst kısmındaki küçük çemberin içinde yatay yerleştirilmiş 6 adet ampul duyu vardır. Bu küçük çemberden, kristal damlalarla süslü alttaki büyük çembere uzanan küçük dikdörtgen düğmelerden oluşan 26 sıra kristal zincir dizisi bulunur. Kollarda, sarkan 6 adet ve çemberlerde, her çelenk içinde 1 adet damla kristal yerleştirilmiştir. Yaklaşık gövde uzunluğu $81,5 \mathrm{~cm}$, çap1 $88 \mathrm{~cm}$ 'dir. 2 adet avize (YLZ-AV 207 ve 1-YLZ-AV 208) tek katlı ve sekiz kolludur. Boğumlu kaideden yukarı doğru kıvrılan kollar yaprak bezemelidir. Yıldız tabaklı mumluklarla biten kollar kristallerle süslenmiştir. Askı zincirleri ve tavana bağlantı aparatı özel tasarlanmıştır. Yaklaşık gövde uzunluğu $72 \mathrm{~cm}$, genişliği 55 cm'dir. İki katlı ve on beş kollu diğer bir avize (YLZ-AV 252), bunlarla tıpatıp aynı özelliklere sahiptir. Oldukça büyük olan iki katlı avize (YLZ-AV 255), yaklaşık 1,27 m uzunluğunda ve 1,32 m çapındadır (G. 6). Üst katı on kollu, alt katı yirmi kolludur. Alt kolları rozetli çemberle birbirine bağlıdır. Yukarı kıvrılan kolları yaprak motifleriyle süslü, mumlukları yıldız tabaklıdır. Kollarından kare ve damla kristaller sarkmaktadır. Alt göbekten aşağıya doğru küçük kare kristallerden oluşan zincir süslemeler bulunmaktadır. Üç katlı büyük avizelerden biri (YLZ-AV 254) yaklaşık 2,16 m gövde uzunluğunda ve 1,70 m çapındadır. Gövdesi, uzun bir boru üzerinde belirli aralıklarla yerleştirilmiş göbekler ve süslemelerle oluşturulmuştur. Yukarı kıvrılan kollar, yaprak motifleri ile bezelidir. En üst kat sekiz, 
orta kat on iki, en alt sıra on dört kolludur. En alt sıradaki kollar içten geçen 1,70 $\mathrm{m}$ çapındaki bir çembere birleştirilmiştir. Kollarındaki askı yerlerinden kristallerinin söküldüğü anlaşılmaktadır. Diğer üç katlı yıldız avize (YLZ-AV 253) yaklaşık 1,32 m gövde uzunluğunda ve orta katı 75,5 cm çapındadır. Bu avizenin alt katı sökülmüş olduğu için toplam çapı belirlenememiştir. Boğumlu gövdesi bitkisel bezemelerle süslüdür. Üst kat altı, orta kat on ve en alt kat on sekiz kolludur.

Yildız aplik (1-YLZ-APL185-204): İki kollu aplikler yukarı doğru kıvrılan, bitkisel bezemeli kollarının ucunda yıldız çiçeği biçimli tabaklardan oluşmaktadır. Kollar kristal sarkıtlarla süslüdür. Bir kolda 13 grup kristal vardır. Bir kristal grubu 1 adet damla biçimli kristal ve1 adet küçük kare kristal şeklinde sıralanmıştır. Apliklerin yaklaşı uzunluğu $40 \mathrm{~cm}$, genişliği $30 \mathrm{~cm}$, derinliği $18 \mathrm{~cm}$ 'dir. Apliklerden iki adedi yakın dönemde imal edilmiştir.

Yıldız grubu, oldukça sağlam durumdadır. Avizelerden bazısı büyüklüğü nedeniyle sökülmüş hâlde depolanmıştır. Avize ve apliklerin kollarında, gövdeye bağlantı yerlerindeki gevşemeler sonucu deformasyonlar, az sayıda kırık tespit edilmiş̧ir. Birleştirilerek yerlerine asılacakları için, mevcut kırıkların sarı kaynakla kaynaklanması, gevşemiş aksamların sağlamlaştırılması gereklidir. 1-YLZ-AV 206 envanter numaralı avizenin bağlantı çubuğu ve büyük çember bağlantısındaki kırık taşıma özelliği yeniden kazandırılacak şekilde onarılmalıdır. Kollar ve gövde yüzeylerindeki oksitlenme, korozyon ve kir tabakası için mekanik temizlik ve bakım çalışmalarının yapılması önerilmiştir.

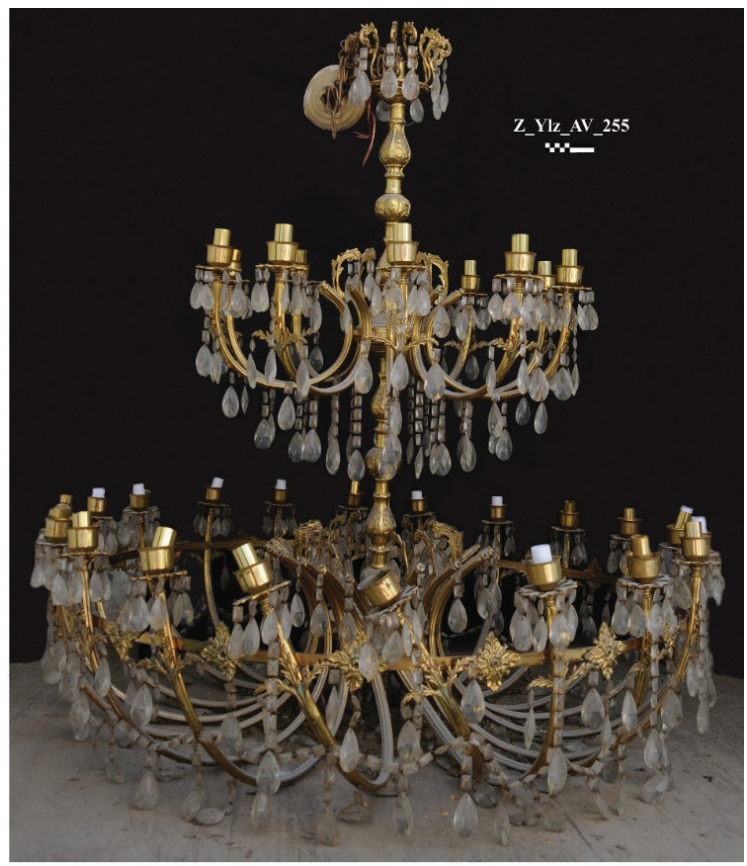

G. 6. Yıldız grubu avize (YLZ-AV 255) depodaki durumu (I. Özsait Kocabaş, 2015) 


\section{Kristal grubu}

Depoda bu gruba dâhil 4 adet kristal avize belgelenmiştir. Ayrıca bina içinde Z-16 numaralı odada kurulumu ve onarımı sürmekte olan bir kristal avize daha olduğu tespit edilmiştir. Rektörlük makam odasına ait olan bu avize kayıtlara geçirilmiş ancak onarımı başladığı için envanter numarası verilmemiştir. Kristal avizelerde taşıyıcı olarak demir askı, çember biçimli konstrüksiyon ve özel tasarımlı zincirler kullanılmıştır. Kristal gruptaki avizelerin tarihi ve estetik değerleri yüksektir. Her birinin kendine özel tasarlanmış fanusları vardır. Elektrik tesisatı kolların dışından geçmektedir. Kristal avizeler birinci katta rektör toplantı odası (1K-59A), rektörlük makam odası (1K-60), rektör sekreteri odası (1K-01A), ikinci katta doktora salonu 3 (2K-30) ve mavi salon yan odasında (2K-60) asılidir.

Yaklaşık olarak 1,37 m uzunluğundaki rektör toplantı odası avizesinin (1-KR-AV 355), demir aksamla taşınan boğumlu kristal gövdesi (G. 7a) ve sekiz adet büyük kristal kesme kolu vardır. Ana kollar çiçek biçimli cam bir fanusun içinde bulunan $32 \mathrm{~cm}$ çapında metal çemberden çıkmaktadır. Bu kolların uçlarından üç adet kıvrımlı küçük kol uzanır. Bunların her birinde, çiçek çanakları içindeki goncalar şeklinde tasarlanmış kristal yuvalara oturan uzun, lale biçimli, üçgen kesimli ağzı olan fanuslar bulunmaktadır. Buradaki silindirik metal duyların içinde uzun mumluklar için tasarlanmış, mantar tıpalar içinden çıkan, ayarlanabilir metal duy sistemi belirlenmiştir. Elektrik tesisatı goncaları delerek duya bağlanmaktadır (G. 7b). Avize, büyük prizmatik, yuvarlak ve damla biçimli kristal sarkıtlarla süslenmiştir. Sarkıt kristaller metal tellerle birbirine bağlanarak zincir oluşturmuştur.
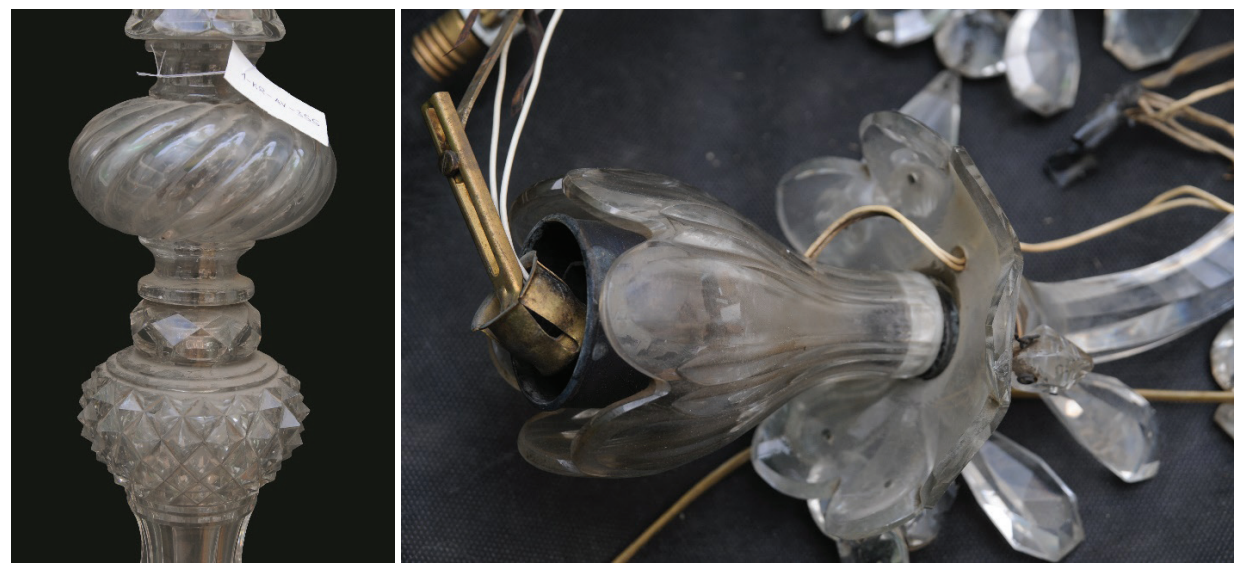

G. 7. Kristal grubu 1-KR-AV 355 numaralı avize; a) kristal gövde (solda), b) duy düzeneği (sağda) (E. Şener, 2015)

Mavi salon yan odasının, boğumlu kristal gövdesi olan iki katlı avizesi (2-KR-AV 387) yaklaşık 1,54 m uzunluğunda ve 1,50 m çapındadır. Alt katta yiv bezemeli kristal çanak içinde bulunan metal çemberdeki yuvalardan çıkan on iki adet kıvrımlı kalın 
kristal kol, ucundan üç ince dala ayrılan ve burada kristal tabaklarla çiçek açan şekilde tasarlanmıştır. Üst katta orta kalınlıkta kıvrımlı kollar taşıyıcı çemberdeki yuvalara yerleştirilmiştir. Bu kolların bitiminde, uzun, lale biçimli fanuslar, çiçek çanakları ve içinde mumluklar ve metal duylar bulunan çiçeklerin içine oturmaktadır. Gövdenin üst kısmında, kristal çanak içindeki metal konstrüksiyondan yukarı doğru çıkan uçları volütlü kristal çubuklar ve bunların ortasında çiçek biçimli üst parçası bulunmaktadır. Kristal sarkıtları, düğme ve damla biçimlidir.

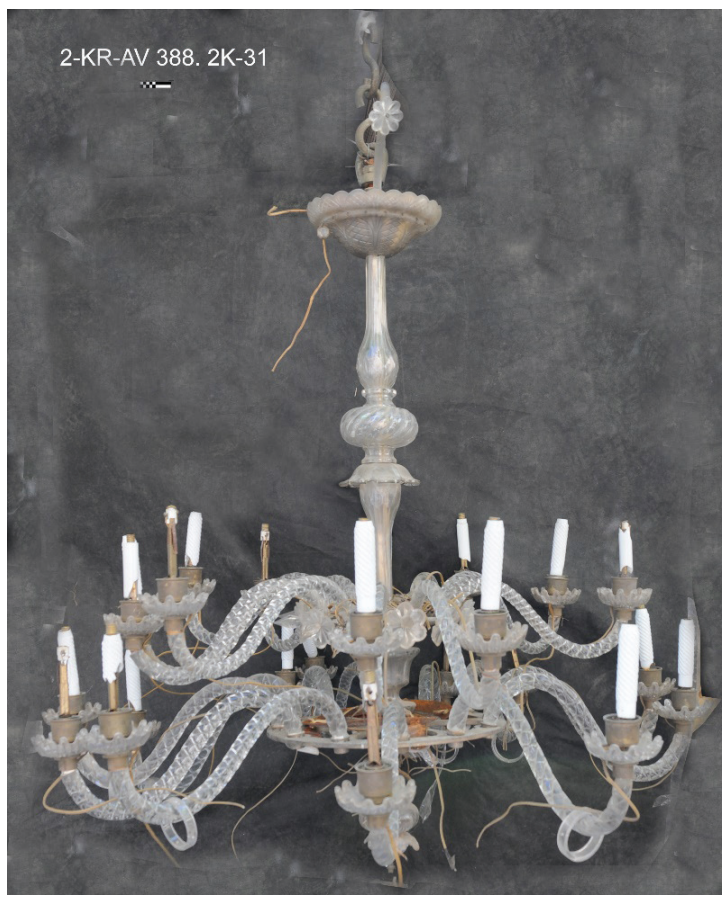

G. 8. Kristal grubu 2-KR-AV 388 numaralı avize parçalarının bir araya getirilerek kurulmuş hali (T. Y1lmaz, 2015)

Doktora salonu 3'ün kristal avizesi (2-KR-AV 388) 1,40 m uzunluğunda ve 1,24 m çapındadır. Kolları boğumlu kristal gövdesinin alt kısmındaki iki taşıyıcı çembere oturmaktadır (G. 8). Altta on iki kristal kol ucunda çiçek biçimli tabaklar, bunların içinde uzun lale biçimli fanusların oturtulduğu metal yuvalardaki porselen mumluklar bulunmaktadır. Üst katta da aynı şekilde on iki adet kol mevcuttur. Avize kristal sarkıtlar yerine küçük kristal çiçeklerle süslenmiștir. Gövdenin en üst kısmında, oldukça eski ve ince işçilikli çiçek biçimli kristal çanaktan yükselerek kıvrılan ince kristal çubuklarda küçük çiçekler vardır. Elektrik tesisatı mantar içinden çıkan metal aksamla yapılmıştır. Diğer kristal avize tamamen sökülmüş durumdadır (1-KR-AV 402). Gövdesi dışındaki bütün aksamları kutulanmıştır. Kurulmadığı için kol sayısı belirlenememiştir. Kıvrımlı kolların ucunda çiçek biçimli kristal tabaklar, bunların içinde metal duylar bulunmaktadır. 
Sökülmüş halde depolanmış olan kristal avizelerin taşıyıcı sistemleri ve ana kolları büyük oranda sağlamdır (G. 9a). Ancak, ince kollar, kristal çubuk süslemeler, kristal mumluk tabaklar ve diğer kristal aksamlarda yüzeysel aşınma ve oldukça fazla kırık mevcuttur. Kristal sarkıtlarda ve bağlantı tellerinde eksikler belirlenmiştir. Bu avizeler yoğun kristal onarımına ihtiyaç duymaktadır. Ayrıca taşıyıcı metal aksamlarında meydana gelen ve aktif olmayan yüzey korozyonu (G. 9b) için küçük alanlarda bisturi, büyük alanlardaysa dişçi motoru ve metal uçla mekanik temizlik yapılmalı, ardından temizlenen yüzeye \%3'lük Paraloid B-72 sürülerek koruma altına alınmalıdır.
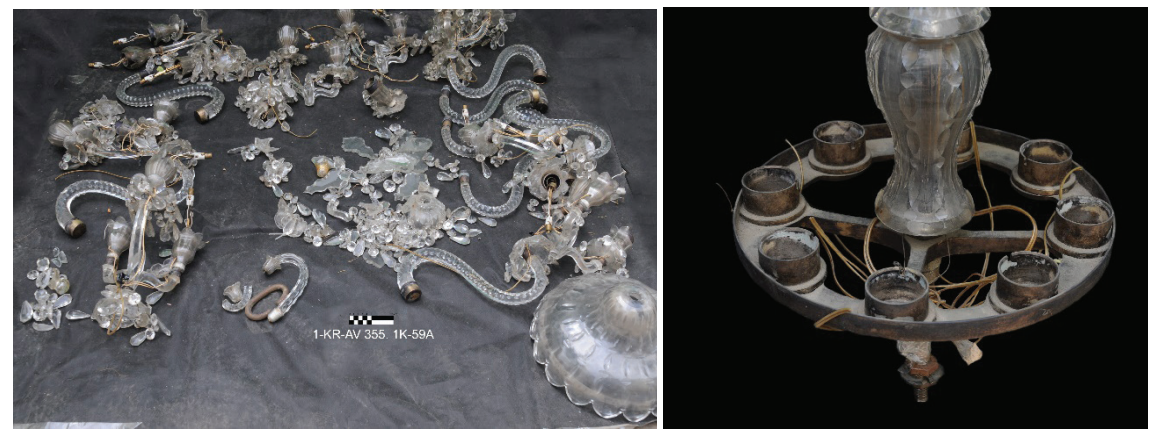

G. 9. Kristal grubu 1-KR-AV 355 numaralı avize; a) sökülmüş parçaları (solda) (E. Şener, 2015),

b) metal aksamlarında korozyon oluşumu (sağda) (I. Özsait Kocabaş, 2015)

\section{Özel grup}

Her biri birbirinden farklı biçim ve tasarımda olan bu grupta 8 adet avize belgelenmiştir. Dal biçimli avize (2-D-AV 358), boğumlu kristal gövdeden oluşan 1,60 m uzunluğunda ve 2,20 m çapında, iki katlı pirinç avizedir. Alt katta, taşıyıcı diskten yapraklarla bezenmiş altı adet büyük kısa kol çıkmaktadır. Bunların içinden ayrılan yaprak bezeli ikincil dallar yükselerek en üstteki küçük taşıyıcı diskle birleşir. Kısa kolların devamındaki uçların her birindeki çanak yapraklarından çıkan yedi adet küçük dal kol ve uçlarında birer fanus bulunmaktadır. Üst kat, yapraklardan oluşan çanaktan çıkan altı adet kolun bitiminde, her bir kol için beşer kola ayrılan dallar şeklindedir. Avizenin alt kısmında ananas biçiminde süsleme elemanı mevcuttur. Alt katta kırk iki, üst katta otuz adet uzun lale biçimli fanus bulunmaktadır. Bir heykel gibi tasarlanarak imal edilmiş avize, bir bitkinin büyüyen ve birbiri içinden çıkan kolları gibi tasvir edilmiştir. Pirinç kolları çeşitli büyüklük ve biçimlerde kristallerle süslenmiştir. Opak cam mumluklar içindeki elektrik tesisatı, mantar tıpalar, eski tip metal ince çubuklar ve iplik örgü muhafazalı kablolarla yapılmıştır. İkinci doktora salonuna (2K-30) ait olan bu avize aydınlatma tarihindeki teknoloji evriminin aşamalarını yansıtan bir grubun nadir örneklerindendir. Dal biçimli avizenin kolları ve diğer elemanları iyi durumdadır. Yerine asılarak kullanılacağı için, küçük kırıkların sarı kaynakla kaynaklanması ve gevşemiş aksamların sağlamlaştırılması gereklidir. Yüzeydeki korozyon ve kir tabakasının temizlenmesi önerilmiştir. 

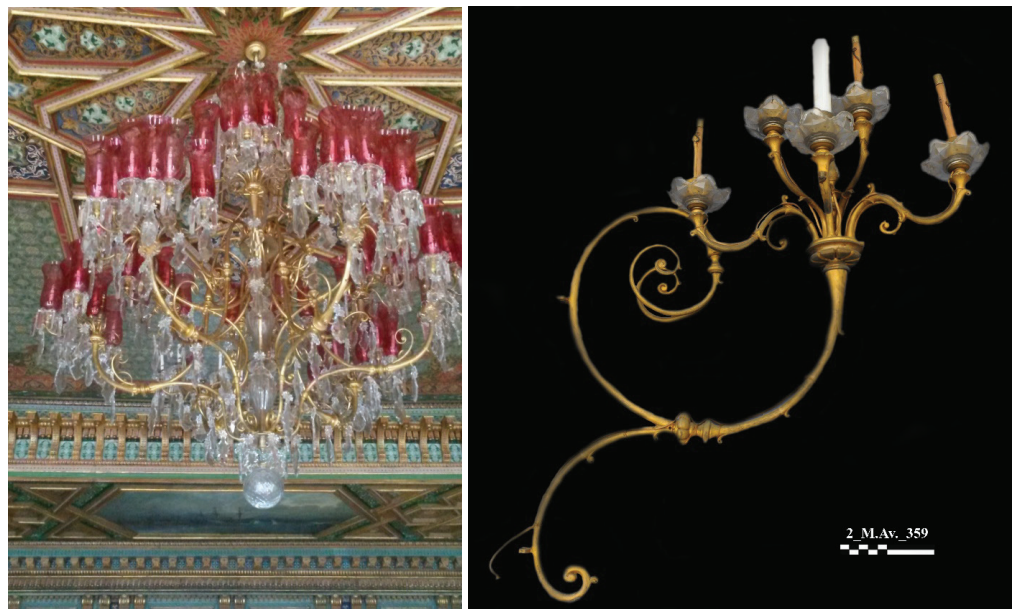

G. 10. Mavi Salonun avizesi (2-M-AV 359); a) restorasyon sonras1 as1lı durumu (solda),

b) kıvrımlı kol detayı (sağda) (I. Özsait Kocabaş, 2015)

Mavi salonun avizesi (2-M-AV 359), iki katll büyük pirinç avizedir (G. 10a). Kolları, stilize bezelye yaprağı ve dallar şeklinde tasvir edilmiş ince ve geniş halkalar hâlindedir. Mum tabakları çiçek biçimli kristallerden yapılmıştır. Tamamen sökülmüş olduğu için genel ölçüleri alınamamıştır. Alt ve üst katı altışar kolludur. Alt katta her bir kolun ucunda yedi adet küçük kol vardır. Üst kat altı adet küçük kola ayrılmaktadır. Bağlantı cıvataları çiçek biçimlidir. Avize çeşitli büyüklük ve biçimlerde kristallerle süslenmiştir. En alt ucunda $15 \mathrm{~cm}$ çapında bir kristal küre asılıdır. Uzun lale biçimli fanusları kırmızı renklidir. Opak cam mumlukların içindeki elektrik tesisatı ucu metal ahşap aksamlı duylar ve iplik muhafazalı kablolarla yapılmıştır (G. 10b). Kolları ve diğer parçalarının büyük çoğunluğu sökülmüş olan avize elemanları iyi durumdadır. Ancak, küçük kırıkların sarı kaynakla kaynaklanması, gevşemiş aksamların sağlamlaştırılması gereklidir. Metal aksamlarında galvanik korozyona rastlanılmıştır. Di-sodyum etilen diamin tetra asetik asitle yüzeyde ince bir tabaka hâlinde olan bakır karbonat (malahit) korozyonu için tampon çözelti şeklinde uygulanması tavsiye edilmiştir. ${ }^{18} \mathrm{Bu}$ alanlar daha sonra \%3'lük Paraloid- B72 sürülerek koruma altına alınmalıdır. Orijinalinde bulunan çiçek biçimli cıvataların korunarak kullanılmasına özen gösterilmelidir.

Hava gazlı avize (2-HV-AV 352), $242 \mathrm{~cm}$ uzunlukta, fanuslarıla beraber $102 \mathrm{~cm}$ çapındadır. Avizenin $55 \mathrm{~cm}$ çapında ve $18 \mathrm{~cm}$ yüksekliğindeki tepsi biçimindeki gövdesi içinde eski tesisatına ait hava gazı boruları günümüze kadar korunmuştur (G. 11a). Elektriğe geçişte açılan küçük deliklerden kablolar çekilmiştir. Ortasında, tavana asıldığ 1 borunun bulunduğu, $10 \mathrm{~cm}$ 'lik göbekten geçen altı adet hava gazı borusunun uçları dönerek yukarı kıvrılmakta ve buralara opak camlı fanuslar oturmaktadır. Te-

18 David Scott, Copper and Bronze in Art: Corrosion, Colorants, Conservation (England: Getty Trust Publications, 2002), 66 . 
sisatı nedeniyle ünik ve çok değerlidir. Birinci doktora salonunda (2K-29) asılı olan bu avize, binadaki en eski avizelerden biri olmasına karşın oldukça iyi durumdadır (G. 11b). Sadece bir kolunun ucundaki fanusu tutan metal halkanın duy bağlantısında kırıklar mevcuttur. Kırıkların sarı kaynakla kaynaklanması ve gevşemiş aksamların sağlamlaştırılmasından sonra yerine asılması uygun olacaktır. Rozans kapağı gevşemiş ve oksidasyona uğramıştır. Yüzeydeki kir ve korozyon tabakası temizlenmelidir.

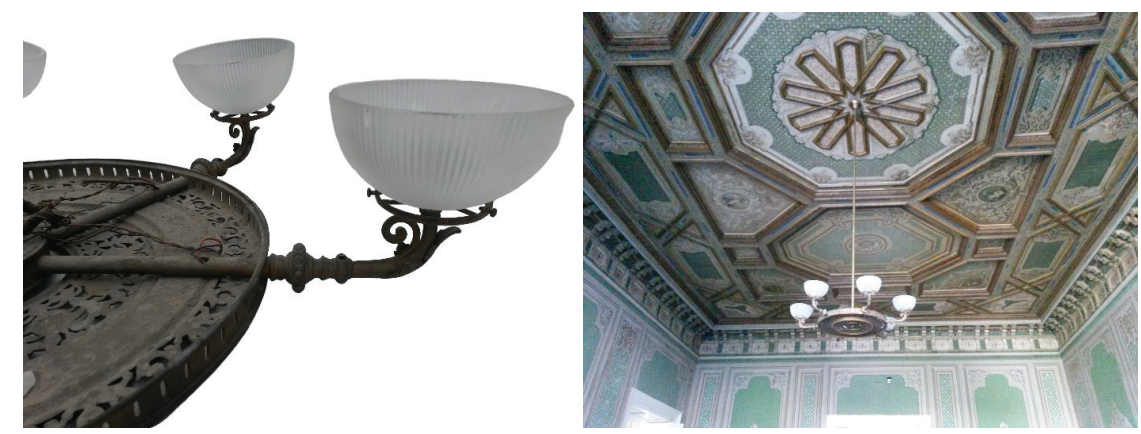

G. 11. Hava gazlı avize (2-HV-AV 352); a) hava gazı boruları (solda),

b) restorasyon sonrası asılı durumu (sağda)

(I. Özsait Kocabaş, 2015)

Murano-gül fanuslu avize (1-G-AV 356), ince uzun boruyla asılmış, sekiz adet ince pirinç kolun çıktığı pirinç çemberden oluşan Murano stilindeki küçük avizedir. Merkez çemberin alt kısmında glop camı vardır. Kolların bitimindeki fanusları gül biçimindedir. Borusu ve gövdesi üzerinde gül dalı ve yapraklarının betimlendiği pirinç süslemeler bulunmaktadır. Gövde yüksekliği yaklaşık $29 \mathrm{~cm}$, çapı $66 \mathrm{~cm}$ 'dir. Rektör danışması odasına (1K-09A) ait olan bu avize, binadaki değerli avizelerden biridir. Gül fanuslarından biri kırılmış ve askı borusu ikiye ayrılmıştır. Diğer parçaları oldukça sağlam ve bütünlüğü korunmuş durumdadır. Metal kollarındaki biçimsel bozulmalar mekanik olarak düzeltilmelidir. Tarihi niteliği nedeniyle gül fanusunun altındaki kırık yapıştııılarak orijinal fanus kullanılmalıdır. Askı borusu üzerine sarılan yapraklı dalların bozulmamasına dikkat edilmeli ve boru sarı kaynakla onarılmalıdır.

Pirinç dallı avize (2-PR-AV 389), kılıçlık (2K-01) odasına aittir. Avize kolları ve gövdesi tamamen sökülmüş olduğu için genel ölçüler alınamamıştır. En alttaki sekiz adet büyük kolun üzerine eklenen dikdörtgen kesitli kollar kıvrımlar yapan ve birbirleri üzerinde yükselen şekilde tasarlanmıştır. Her bir kolda, en altta birer, onun üstündeki kollarda ikişer, bir üstündeki kollarda ikişer ve en üstteki kollarda birer olmak üzere çiçek biçimli tabaklara oturan 48 adet uzun, lale biçimli fanusu bulunmaktadır. Mumlukları opak camdır. Mumluklar içindeki elektrik tesisatı metal çubuklar ve iplik örgü muhafazalı kablolarla yapılmıştır (G. 12a). Birleştirmelerde kullanılan cıvataları çiçek başlıdır (G. 12b). Pirinç kolları çeşitli büyüklük ve biçimlerde kristallerle süslenmiştir. Parçaları eksiksiz olan avize kurulduğunda kendisini taşıyabilecek 
sağlamlıktadır. Ancak, şekillerinde deformasyon olan aksamlarının mekanik olarak düzeltilmesi gereklidir. Yüzeydeki korozyon ve kir tabakası için mekanik temizlik ve temizlenen bölgeye \%3'lük paraloid-B72 sürülmesi önerilmiştir.
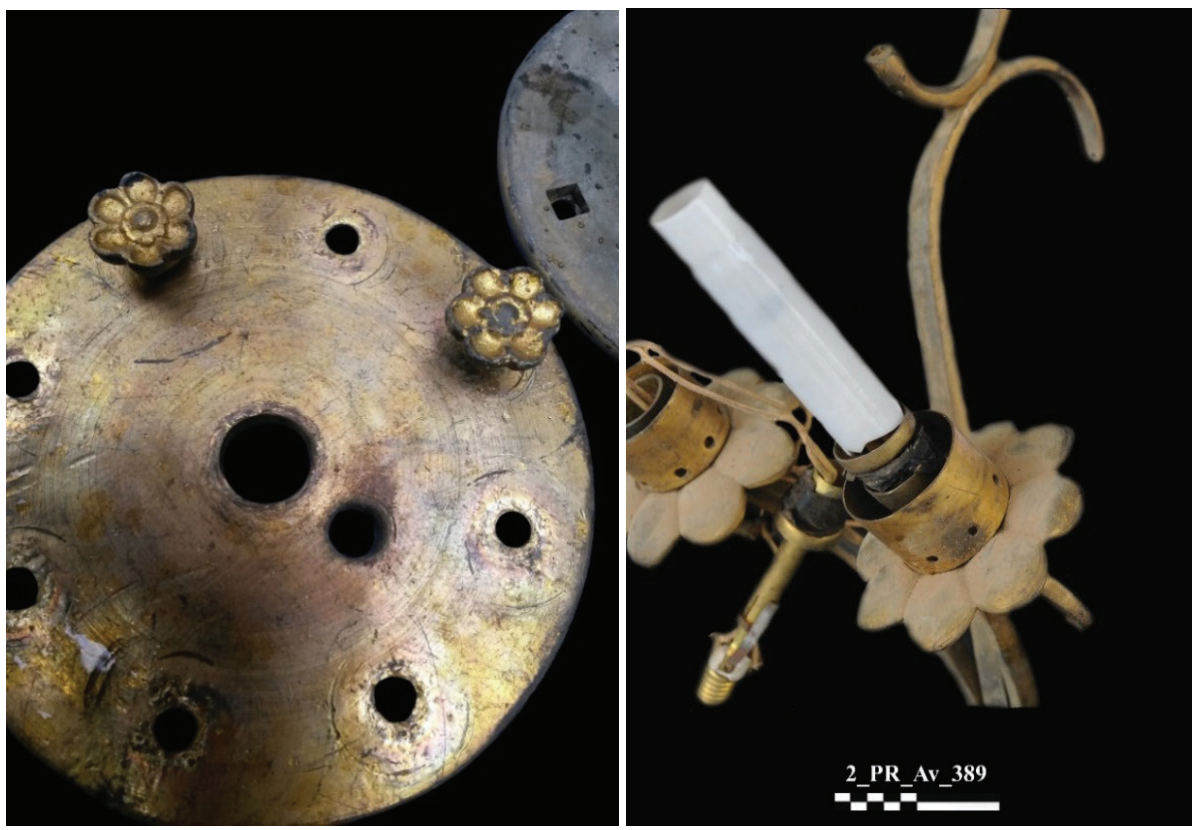

G. 12. Pirinç dallı avize (2-PR-AV 389); a) mumluk detayı (solda), b) taşıyıcı sistem parçası ve çiçek başlı cıvataları (I. Özsait Kocabaş, 2015)

Rektör dinlenme odasında (1K-58) asılı olan yeşil avize (YŞL-AV 251), uzun metal boru taşıyıcısı olan, ortada geniş ve kalın, altta ve üstte daha küçük ve dar olan enli çemberler hâlinde tasarlanmış avizedir. Çemberleri birleştiren beş adet dikdörtgen kesitli içi dolu profil, aynı zamanda kolları oluşturarak aşağı bakan çiçek biçimli fanusları taşımaktadır. Ana gövde yukarıdaki küçük tepeliğe dikdörtgen göbekli plakalardan oluşturulmuş zincirlerle bağlıdır. Gövdesi yaklaşık 2,42 m uzunluğunda, genişliği 70 cm'dir. Avize sağlamlığını korumaktadır. Zincirdeki eksik kısımlar, onu oluşturan dikdörtgen plakaların benzerlerinden yaptırılması yoluyla tamamlanmalıdır. Fanusların asılmasını sağlayan halkaların kopan kısımları onarılmalıdır. Üzerindeki yaldız ve boya tabakası rötuşlanarak gerekli bakım-onarım yapılmalı; elemanların tamamen boyanmasından kaçınılmalıdır.

Geçiş hollerine (1K-59 ve 2K-02) ait 2 adet birbirinin aynı beş kollu küçük pirinç avize (1-AV 357 ve 1-PR-AV 399) belgelenmiştir. Silindir gövdesine bitişik devam eden kolları, köşeli şekilde yukarı dönmekte ve çiçek biçimli fanusları taşımaktadır. Gövdesi yaklaşık $50 \mathrm{~cm}$ uzunluğunda, $53 \mathrm{~cm}$ genişliğindedir. Bu avizeler, diğerlerine göre daha yeni olsa da belli bir dönemin karakteristiğini taşıdıkları için gerekli temizliklerin yapılmasından sonra kullanılması önerilmiştir. 

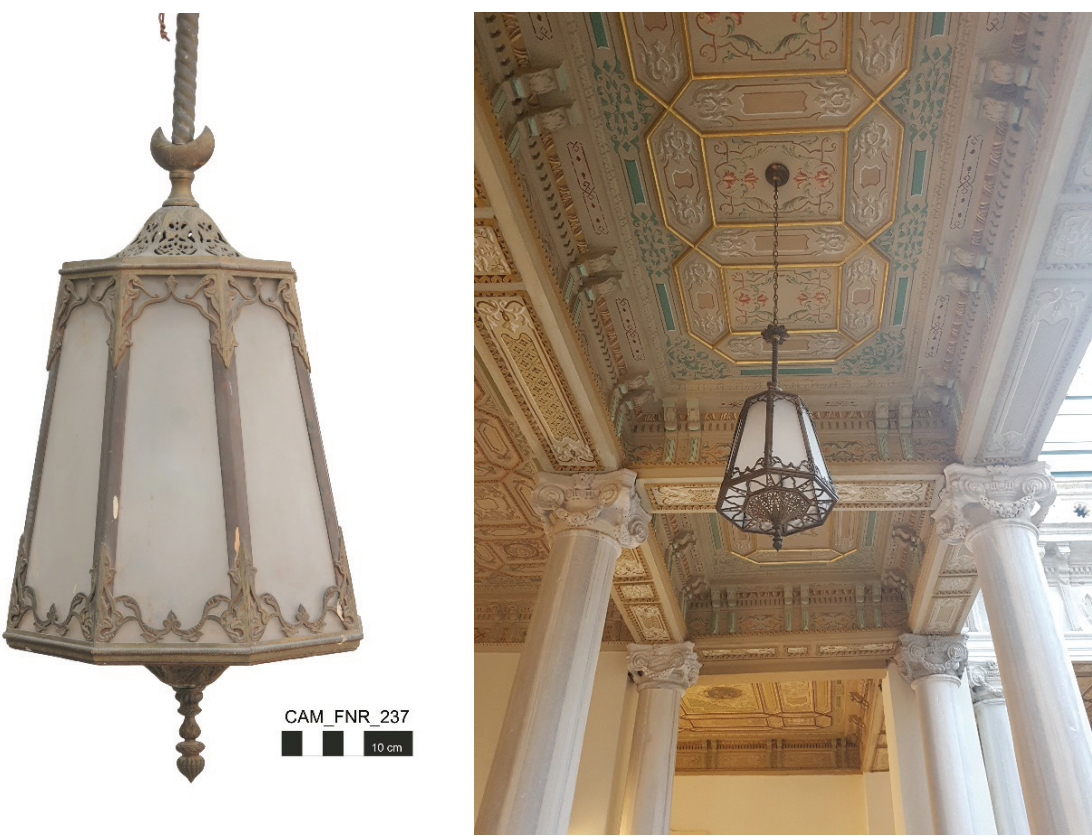

G. 13. Cam fener (CAM-FNR 237); a) korunmuşluk durumu (solda) (M. Sağır, 2015), b) restorasyon sonrası asılı durumu (sağda) (I. Özsait Kocabaş, 2015)

\section{Fenerler}

Dört adet cam fener ve on bir adet altıgen fener olmak üzere, iki farklı tipte fener belgelenmiştir. Cam fenerler (CAM-FNR 236, 237, 362, 398), sekizgen biçimli, altı geniş, üstü dar pirinç konstrüksiyonun arasında bulunan camlardan oluşmaktadır (G. 13a). Konstrüksiyon kenarları cam yüzeyleri tutan şekilde stilize bitkisel motiflerle bezelidir. Burma şekilli boruyla tavana asılan bu fenerler yaklaşık 1,07 m uzunluğunda, $44 \mathrm{~cm}$ genişliğindedir. Cam fenerler B blok birinci kat yan koridorlarda (1K-61 ve 1K-62) asilidir (G. 13b).

Altıgen fenerler (1-FNR 226-235, 403), camsız, bütün yüzleri stilize bitkisel motiflerle bezeli, ajur tekniğinde yapılmıştır (G. 14). Yarım kubbe biçimli üst kısmında bir alem vardır. Üst köşelerinden çıkan yaprak biçimli kancalara takılan zincirlerle asılmışlardır. Taban kısmında bir adet büyük, altı adet küçük damla biçimli şeffaf fanusu vardır. Yaklaşık 1,68 m uzunluğunda ve $40 \mathrm{~cm}$ genişliğinde olan altıgen fenerler, B blok birinci ve ikinci kat koridorlarında ve birinci kat ana holünde (1K-61, 1K-62, 1K-61A, 1K-62B, 2K-62, 2K-63) as1lidir. 


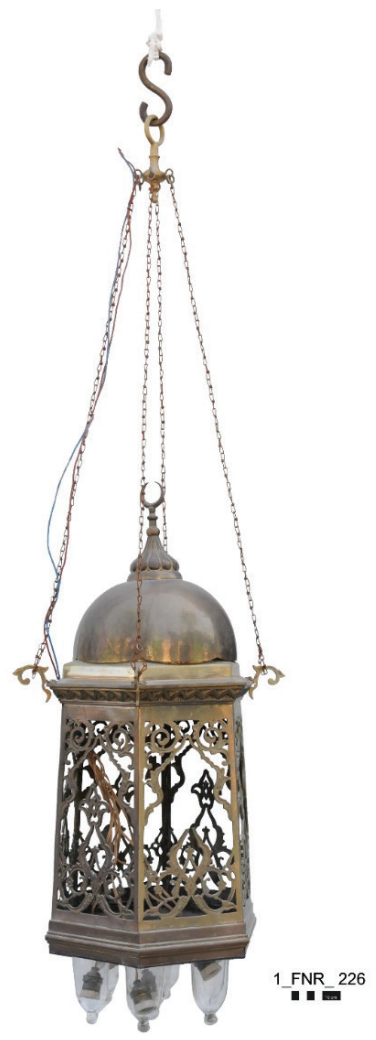

G. 14. Altıgen fener (1-FNR 226) (M. Sağır, 2015)

Fenerler genel olarak iyi durumdadır. Altıgen fenerlerde, yarım kubbe biçimli üst kısımlarının, biçimsel bozulmalar sonucu yerlerine oturmaması (G. 15a), askı köşebentlerindeki ve metal ajurlarındaki kopma ve kırıklar (G. 15b), küçük deformasyonlar belirlenmiştir. Askı zincirlerinde, gevşemeler ve kopmalar vardır. Bir tanesinin kubbeli üst kısmı kayıptır. Taşıyıcı özellikte olan eksik parçaları aslına uygun şekilde imal edilmelidir. Ancak ajurlarında belirlenen bazı eksik kısımların dikkat çekici olmadığı ve bütünlüğü bozmadığ 1 için tamamlanmasına gerek yoktur. Cam fenerlerden ikisinde eksik olan toplam 3 adet cam tamamlanmalıdır. Camı tutma görevleri de olan camlı fenerlerdeki ajurlar onarılmalıdır. Pirinç malzemede oksitlenme, yüzeylerde boya lekeleri ve altıgen fenerlerin ask zincirlerinde yoğun demir oksit tabakası belirlenmiştir. Pirinç aksamlarda polisaj yoluyla yüzey temizliği yapılmalıdır. Zincirlerdeki korozyon mekanik yolla uzaklaştırılmalı ve tannik asitle koruyucu bir tabaka oluşturulmalıdır. Fenerlerin yerlerine asılabilmesi için gerekli olan zincir, kanca ve askı sistemindeki aksamlar fenerlerin tarzına uygun olarak sağlamlaştırılmalıdır. 


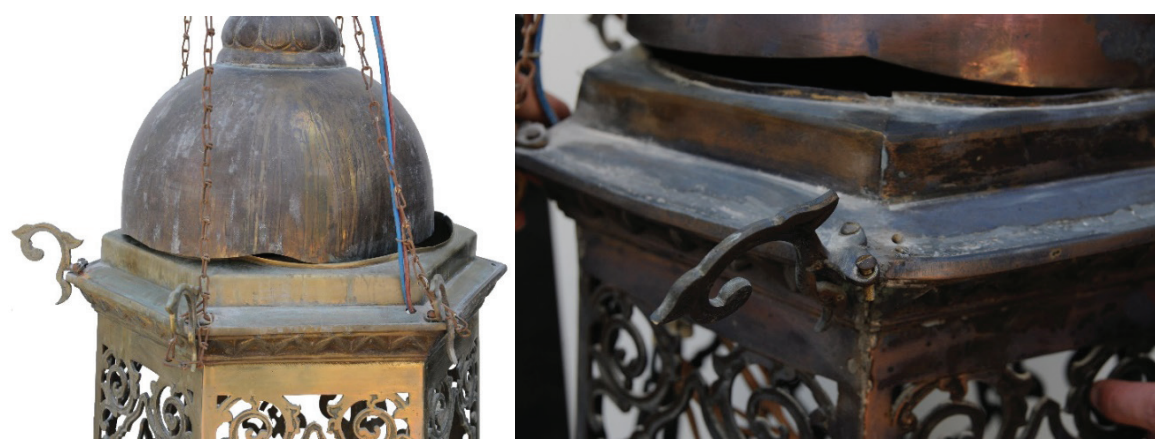

G. 15. Altıgen fenerlerde hasar durumu; a) biçimsel bozulma ve yüzeylerdeki korozyon oluşumu (solda), b) yerinden çıkmış köşebent kancası (sağda) (M. Sağır, 2015)

\section{Değerlendirme ve Sonuç}

Toplamda 564 aydınlatma armatürü üzerinde gerçekleştirilen çalışmaların sonucunda rektörlük binasında bulunan ve yukarıda tipleri ve özellikleri anlatılmış olan, lale, şamdan, yıldız, kristal, özel gruplarındaki avize ve aplikler ile fenerlerin (26 adet avize, 1 adet binadaki kristal avize, 15 adet fener, 206 adet aplik) tarihi eser niteliği taşıdığ belirlenmiştir. Merkez binanın tarihi ve orijinal kısmını oluşturan B bloğunun zemin, birinci ve ikinci katlarında ve diğer blokların zemin kat Z-51 ve birinci kat1K-39, $1 \mathrm{~K}-53,1 \mathrm{~K}-10,1 \mathrm{~K} 23$ ve $1 \mathrm{~K}-09 \mathrm{~A}, 1 \mathrm{~K}-05,1 \mathrm{~K}-58$ numaral odalarında bulunan bu aydınlatma armatürlerinin korunması ve gerekli olan eser prosedüründeki bakım-onarım çalışmalarından sonra tekrar yerlerine kurulması önem taşımaktadır. Merkez binanın, ofislerin bulunduğu yenilenmiş kısımları A ve C bloklarındaki glop, damla, ahşap, küçük kristal-cam grupları, diğer grubuna dâhil olan uzun ve küre fanuslu avizeler (222 adet), bu grupların aplikleri ile şamdan ve yıldız gruplarındaki bazı aplikler ( 88 adet), abajurlar (2 adet) ve yer lambalarının ( 4 adet) yakın tarihlerde imal edildiği tespit edilmiştir. Bunlar, binanın farklı yenileme ve onarım çalışmaları sırasında eklenmiş ya da hediye edilmesi sonucu takılmış olan aydınlatma armatürleridir. Sürdürülen iş ak1şında daha aydınlık mekânların elde edilmesi ihtiyacı doğrultusunda, buralarda bulunan aydınlatma armatürlerinin isteğe göre yerlerine takılması ya da gereken durumlarda yenileriyle değiştirilmesi uygun görülmüştür. Yeni alınacak olan armatürlerin, binanın tarihi kimliğine ve mimari tarzına uygun seçilmesine dikkat edilmelidir.

Eser kapsamında ele alınan avize ve aplikler, 19. yüzyılın ikinci yarısında inşa edilmiş ve 1. derecede tarihi eser kapsamındaki binanın içinde bulundukları, binanın mimarisi ve içindeki kalem işlerinden ayrı düşünülemeyecek tamamlayıcı dekoratif unsurlar oldukları için eskilik özelliği ve tarihi belge niteliği taşımaktadır. Bu tarihten itibaren, avize tasarımları ve yapım tekniklerini gösteren bir süreci yansıttıkları, aynı zamanda hava gazından elektriğe geçişteki aydınlatma teknolojisinin gelişim aşamalarına örnek oluşturmaları nedeniyle tarihi belge niteliğine sahiplerdir. Bunların yanı sıra ihtişamlı tasarımları ve üzerlerindeki ince işçilik nedenleriyle estetik değerleri yüksektir. 
Eser niteliği taşıyan aydınlatma armatürlerinin durumu kristal grubu dışında oldukça iyidir. İskeletleri kendilerini taşıyacak sağlamlıkta olan avize ve aplikler, basit mekanik onarımlar ve gerekli yüzey temizliğinden sonra yerlerine asılarak kullanılmalıdır. ${ }^{19} \mathrm{Te}-$ mizlik, bakım ve onarım işlemleri sırasında oluşabilecek herhangi bir zararı önlemek için eserin malzemesine, işlemesine ve yapısal özelliklerine uygun temizlik yöntemleri ve malzemeleri seçilmelidir. Kristal avizelerde orijinal parçaların restorasyonuna öncelik verilmeli, kırık parçaların yenileriyle değiştirilmesi en son çözüm olarak değerlendirilmelidir. Ancak gereken durumlarda, eksik parçaların aslına, kendi avizesinin tasarımına ve mevcut örneklerin biçim ve boyutuna uygun olarak imal edilmesi mümkün olabilir. Kristal avizeler ve büyük pirinç avizeler sökülerek depolanmış; avizelerin kristalleri ve fanusları ayrı kutularda koruma altına alınmıştır. Bu avizelerin kurulumu sırasında, bilirkişilerden, fotoğraflardan ve hazırlanmış envanter kayıtlarından yardım alınmalı, taşıyıcı sistemin, kolların ve sarkıtların orijinal tasarıma uygun birleştirilmesine dikkat edilmelidir. Sökülmüş olan kristal sarkıtların kutularda aranıp bulunması, bunların doğru yerlerine takılması ve daha sonra eksik kalan yerler için gerekiyorsa yeni kristal sarkıt üretimi yapılması önerilmiştir. Bazı avize fanuslarında kırık ve çatlaklar mevcuttur, bazı fanuslar sayıca eksiktir. Bunların yapıştırılarak kullanılması, gereken durumlarda eksik fanusların aslına uygun olarak imal edilmesi önerilmiştir. Yeni üretim olan fanus ve kristal parçaların görünmeyen kısımlarında imalat tarihinin yazılması önem taşımaktadır. Avizelerin kristal düğmelerini, sarkıtlarını birbirine ya da avize konstrüksiyonuna bağlayan metal tellerde korozyon, gevşeme ve kopmalar tespit edilmiştir. Gerekli olan yerlerde bu teller taşıyıcı özellikleri nedeniyle yenilenmelidir. Kurulum sırasında kullanılacak vida ve somunlar, avizenin tasarımına uygun biçim ve büyüklükte seçilmelidir. Kristal ve pirinç avizelerin özel tasarım olan askı zincirlerinin eksik ve kopmuş halkaları, aslına uygun şekilde onarılarak kullanılmalıdır.

Sökülme sırasında kesilen elektrik kablolarının tekrar kullanılamayacağı aşikârdır. Ancak, orijinal iplik örgü muhafazalı kablolar, ahşap ve metal duy sistemleri ve balsa mumluklar günümüze kadar ulaşmıştır. Üstelik farklı avize ve apliklerin eski elektrik tesisatları, aydınlatma teknolojisi gelişimin aşamalarını gösteren tipolojik bir sıra vermektedir (2-D-AV 358, 2-M-AV 359, 2-PR-AV 389, 3 kollu şamdan aplikler, 1-KRAV 355, 2-KR-AV 387, 2-KR-AV 388). Bu durumun dikkatle değerlendirilmesi, konuya yönelik bir çözüm bulunmadan, özellikle bu nitelikteki avizelerin elektrik tesisatı

19 Aydınlatma armatürlerinde uygulanan koruma ve onarım uygulamaları için bkz. Karen Abend, Linda Borsch, Julia Day, Janis Mandrus ve Lisa Pilosi, "Conservation of Eighteenth Century Lighting Fixtures in The Metropolitan Museum of Art," The Artifact, Its Context and Their Narrative: Multidisiplinary Conservation in Historic House Museums (ICOM-CC\&DEMHIST), November 6-9, 2012, ed. Kate Seymour ve Malgorzata Sawicki (Los Angeles: Getty Research Institute, 2012) Erişim 24.10.2019, http://www.icom-cc.org/269/\#. XbF7oOgzZPZ; Julie A. Reilly ve Martin Mortimer, "The Care and Conservation of Glass Chandeliers," Journal of the American Institute for Conservation 37.2 (1998), 149-172; Sandra Davidson, Conservation and Restoration of Glass (Oxford: Butterworth-Heinemann, 1989); Sandra Davidson, "Cut Glass Chandeliers: Dismantling, Cleaning, Recording, and Restoring," In Preprints of the Contributions to the United Kingdom Institute for Conservation 30th Anniversary Conference (London: UKIC, 1988), 90-93. 
ve onarımlarına başlanılmaması önerilmiştir. Elektrik mühendisleri tarafından yapılan değerlendirmeler sonucunda, binanın yangın güvenliği açısından avize ve apliklerin elektrik tesisatlarının yenilenmesi gerektiği rapor edilmiştir. Bu doğrultuda, bina içinde yerlerine asılan avize ve apliklerin elektrik tesisatları özellik ve biçimlerine uygun şekilde yeniden düzenlenmiş ve duylarına 1sı yaymayan mum biçimli led ampuller takılmıştır. Teknoloji tarihinden kesit sunan bilgilerin korunması adına, eski elektrik tesisatına ait orijinal malzemelerin ve onarımlarda kullanılmayan kırık avize parçalarının saklanması yönünde karar alınmıştır. Tarihin tanıkları olan bu parçalar, zamanı geldiğinde değerlendirilmesi, konuyla ilgili birimlerde araştırma, sergileme ve ders malzemesi olarak kullanılması amacıyla kutulanarak saklanmıştır.

İstanbul Üniversitesi Rektörlük Merkez Binası'nın eser niteliğindeki aydınlatma armatürlerinin, rapordaki öneriler doğrultusunda, bakım ve onarım çalışmaları gerçekleştirilmiş ve yerlerine montajı yapılmıştır. Bu süreç, Taşınabilir Kültür Varlıklarını Koruma ve Onarım Bölümü ve Rektörlük yetkililerinin ortak denetimleriyle yürütülmüştür.

Hakem Değerlendirmesi: Dış bağımsız.

Çıkar Çatışması: Yazarlar çıkar çatışması bildirmemiştir.

Finansal Destek: Yazarlar bu çalışma için finansal destek almadığını beyan etmiştir.

Peer-review: Externally peer-reviewed.

Conflict of Interest: The authors have no conflict of interest to declare.

Grant Support: The authors declared that this study has received no financial support.

\section{Kaynakça/References}

Abend, Karen, Linda Borsch, Julia Day, Janis Mandrus ve Lisa Pilosi. "Conservation of Eighteenth Century Lighting Fixtures in The Metropolitan Museum of Art." The Artifact, Its Context and Their Narrative: Multidisiplinary Conservation in Historic House Museums (ICOM-CC \& DEMHIST), November 6-9, 2012. Ed. Kate Seymour ve Malgorzata Sawicki. Los Angeles: Getty Research Institute, 2012. Erişim 24.10.2019. http://www.icom-cc.org/269/\#.XbF7oOgzZPZ

Aksoy, Asu, Funda Açıkbaş ve Ayşenur Akman. "Silahtarağa Elektrik Santralı'nın Hikâyesi." Silahtarağa Elektrik Santralı 1910-2004. Haz. Asu Aksoy. İstanbul: İstanbul Bilgi Üniversitesi Yayınları, 2009.

Can, Cengiz. “İstanbul'da 19. Yüzyıl Batılı Levanten Mimarların Yapıları ve Koruma Sorunları.” Doktora Tezi, Yıldız Teknik Üniversitesi, 1993.

Can, Cengiz. "Harbiye Nezareti Binası.” Dünden Bugüne İstanbul Ansiklopedisi. c. 3. İstanbul: Tarih Vakfi Yayınları, 1994, 550-551.

Davidson, Sandra. "Cut Glass Chandeliers: Dismantling, Cleaning, Recording, and Restoring." In Preprints of the Contributions to the United Kingdom Institute for Conservation 30th Anniversary Conference, 90-93. London: UKIC, 1988.

Davidson, Sandra. Conservation and Restoration of Glass. Oxford: Butterworth-Heinemann, 1989.

Dinçel, Adnan. “Türkiye'de Elektriğin İlkleri Silahtarağa Santralistanbul.” Kaynak Elektrik Dergisi Ağustos 2007 (2007): 61-64. 
Engin, Vahdettin ve Ufuk Gülsoy. Osmanlı'dan Cumhuriyet'e Istanbul'da Elektrik. İstanbul: İETT Yayınları, 2016.

Göncü, Tuncay Cengiz. “Dolmabahçe Sarayı'nın İnşa Süreci, Mekân ve Teşkilat.” Doktora Tezi, İstanbul Üniversitesi, 2015.

Göncü, Tuncay Cengiz. “Beylerbeyi Sarayı'nın İnşa Süreci, Teşkilâtı ve Kullanımı.” Yüksek Lisans Tezi, İstanbul Üniversitesi, 2006.

Gülersoy, Çelik. "Dolmabahçe Sarayı.” Skylife. Haziran 1994: 43-48.

Güner, Deniz. “Akaretler Sıra Evleri: Bir Multigrafik Okuma Denemesi.” Dolmabahçe: Mekânın Hafizası. Haz. Bahar Kaya (İstanbul: İstanbul Bilgi Üniversitesi Yayınları, 2005), 207-247.

Günergun, Feza ve Sevtap Kadığlu. “İstanbul Üniversitesi’nin Yerleşim Tarihi Üzerine Notlar.” Osmanlı Bilimi Araştırmaları 8.1 (2006): 136-163.

Karahüseyin, Güller. Shedding Light on an Era: The Collection of Lighting Appliances in 19th Century Ottoman Palaces. İstanbul: TBMM Milli Saraylar, 2009.

Karahüseyin, Güller. Milli Saraylar Aydınlatma Araçları Koleksiyonu. İstanbul: TBMM Milli Saraylar, 1998.

Küçükerman, Önder. “Dolmabahçe Sarayı ve Ünlü Kristalleri.” Skylife. Kasım 1997: 49-60.

Mazak, Mehmet. “Anadolu Yakasının İlk Sanayi Tesislerinden Kuzguncuk Gazhanesi ve Üsküdar.” IV. Üsküdar Sempozyumu 3-5 Kasım 2006 Bildirileri 1 (2007): 179-184.

Özdemir, Nazmiye. "İmparatorluktan Cumhuriyet'e Türkiye'de Elektriğin Tarihsel Gelişimi (18501938)." Osmanlı Medeniyeti Araştırmaları Dergisi 2.3 (2016): 17-32.

Reilly, Julie A. ve Martin Mortimer. "The Care and Conservation of Glass Chandeliers." Journal of the American Institute for Conservation 37. 2 (1998): 149-172.

Scott, David. A. Copper and Bronze in Art: Corrosion, Colorants, Conservation. England: Getty Trust Publications, 2002.

Scott, David A. ve Gerhard Eggert. Iron and Steel in Art: Corrosion, Colorants, Conservation. England: Archetype Publications, 2009.

Tuncer, Akın. "Osmanlı Seraskeri Binası ve Seraskeri Köşkleri Dekorasyonu Üzerine Bir Araştırma.”Yüksek Lisans Tezi, Mimar Sinan Güzel Sanatlar Üniversitesi, 2005. 